\title{
Empirical Goodwill Research: Insights, Issues, and Implications for Standard Setting and Future Research
}

\section{Amir Amel-Zadeh, Martin Glaum \& Thorsten Sellhorn}

To cite this article: Amir Amel-Zadeh, Martin Glaum \& Thorsten Sellhorn (2021): Empirical Goodwill Research: Insights, Issues, and Implications for Standard Setting and Future Research, European Accounting Review, DOI: 10.1080/09638180.2021.1983854

To link to this article: https://doi.org/10.1080/09638180.2021.1983854
(c) 2021 The Author(s). Published by Informa UK Limited, trading as Taylor \& Francis Group

\section{Ft}

View supplementary material $๘$

\section{曲 Published online: 25 Oct 2021.}

Submit your article to this journal $\pi$

LII Article views: 234

Q View related articles $\sqsubset$

View Crossmark data 


\title{
Empirical Goodwill Research: Insights, Issues, and Implications for Standard Setting and Future Research
}

\author{
AMIR AMEL-ZADEH @*, MARTIN GLAUM @*** and THORSTEN SELLHORN ๑ † \\ *Saïd Business School, University of Oxford, Oxford, UK; **WHU - Otto Beisheim School of Management, Vallendar, \\ Germany; \\ ${ }^{\dagger}$ Munich School of Management, LMU München, Munchen, Germany
}

(Received: November 2019; accepted: September 2021)

\begin{abstract}
This paper reviews the empirical literature on the determinants and decision usefulness of goodwill reporting. We structure our discussion around five guiding questions that reflect longstanding policy issues: recognition, initial and subsequent measurement, disclosure, and the role of governance and monitoring. In addition to summarizing the findings, we assess the validity of the evidence. Our review indicates that goodwill amounts, on average, are associated with the underlying economics of the combining firms but are also shaped by managerial incentives and institutional context. Empirical research does not allow us to conclude whether current goodwill accounting rules provide for an optimal degree of discretion. Nonetheless, our analysis yields a number of policy implications and research suggestions. In addition to pointing out new research questions that could be addressed by further archival research, we advocate reproduction studies to test the generalizability of existing findings across contexts, and we encourage standard setters to initiate quasi-experiments to generate causal evidence and to render policymaking more accountable. We further suggest that researchers make more use of behavioral theories and non-archival methods to elucidate the motives and interactions of decision-makers in goodwill accounting.
\end{abstract}

Keywords: Goodwill; business combinations; decision usefulness; validity

JEL codes: M41; G34

\section{Introduction}

This paper reviews the empirical literature on goodwill reporting to achieve several objectives. First, we present a systematic overview of an important and dynamic field of accounting research. Second, we critically assess extant studies on goodwill accounting, pointing out gaps and identifying validity issues that are both specific and common to this area of research. Third, taking into account these validity concerns, we summarize the conclusions that can be drawn from empirical research for evidence-based standard setting on goodwill reporting. Fourth, we point out avenues for further research to produce new and deeper insights and to advance accounting

Correspondence Address: Amir Amel-Zadeh, University of Oxford, Said Business School, Park End Street, OX1 1HP, UK. Email: amir.amelzadeh@sbs.ox.ac.uk

Paper accepted by Hervé Stolowy 
theory - avenues that could improve archival research, which currently dominates empirical goodwill accounting research, as well as avenues for non-archival research.

We focus on goodwill research for several reasons. First, goodwill is highly material, often representing the single largest item on firms' balance sheets (e.g., European Financial Reporting Advisory Group, 2016). Second, goodwill accounting is highly discretionary, making it an 'extreme case' (e.g., Flyvbjerg, 2006) for testing theories in financial reporting - e.g., theories relating to the decision usefulness of accounting information and the determinants of reporting choice. Third, goodwill accounting, and specifically the impairment-only approach (IOA), introduced by the US Financial Accounting Standards Board (FASB) in 2001 and the International Accounting Standards Board (IASB) in 2003, is a deeply controversial accounting policy issue (e.g., Accounting Standards Board of Japan, 2017; Ramanna, 2008; Watts, 2003). The former IASB Chairman Hans Hoogervorst pointed out that under the IOA "impairment is almost bound to be "too little, too late". ${ }^{1}$ In the light of this criticism, the IASB and the FASB are currently reviewing their accounting standards for goodwill. ${ }^{2}$

Our work adds to previous literature reviews on goodwill accounting (e.g., Wen \& Moehrle, 2016, and d'Arcy \& Tarca, 2018) in three ways. ${ }^{3}$ First, we critically discuss validity problems in goodwill research. Unlike systematic reviews in other domains such as medicine, literature reviews in accounting have typically not explicitly addressed validity problems and their consequences for evidence quality. However, for accounting researchers as well as policymakers interested in drawing conclusions from goodwill research, understanding the robustness of prior research is important, especially where aggregate findings appear inconclusive. We therefore highlight validity problems in goodwill accounting research and present potential remedies for these problems in future research. Second, whereas Wen and Moehrle (2016) focuses on US GAAP goodwill accounting requirements and US-based studies, and d'Arcy and Tarca (2018) concentrates on IFRS requirements, we complement their insights by comprehensively covering high-quality goodwill studies regardless of accounting regime. Third, and more importantly, goodwill accounting research continues to progress, and recent studies have addressed new research questions and brought new insights that were not available to previous literature reviews - for example, the moderating role of governance mechanisms and external monitoring in firms' goodwill-related reporting decisions. Altogether, we identify a total of 79 empirical goodwill studies from leading academic accounting journals, 59 of which have not been covered in the two prior reviews.

Using a set of key questions derived from an overview of the institutional background of goodwill accounting, we relate the studies to core issues in accounting research and policymaking (e.g., Scott, 2019), namely (1) recognition and the asset nature of goodwill, (2) purchase price allocation and initial measurement of goodwill, (3) subsequent measurement and the effectiveness of the goodwill impairment test, and (4) presentation and disclosure. We also address (5) studies that investigate the moderating role of corporate governance, auditing, and other forms of monitoring. In each of these areas, we summarize the key findings of interest to future researchers as well as potentially helpful to policymakers in their efforts to improve current goodwill accounting standards. Figure 1 provides an overview. We then discuss validity problems (construct, internal and external validity), point to techniques - some employed in prior studies - that might address these problems, and offer suggestions to take the field forward.

\footnotetext{
${ }^{1}$ Hans Hoogervorst, 'Are we ready for the next crisis', Speech, Washington, DC, 11 December 2018; available at: https:// www.ifrs.org/news-and-events/2018/12/speech-are-we-ready-for-the-next-crisis/ (retrieved June 2021).

${ }^{2}$ We discuss the recent developments in more detail below; see Section 2.3.

${ }^{3}$ It also expands on prior reviews focused on particular aspects of goodwill accounting, e.g., impairments (Schatt et al., 2016), and it also builds on the unpublished review paper by Boennen and Glaum (2015).
} 


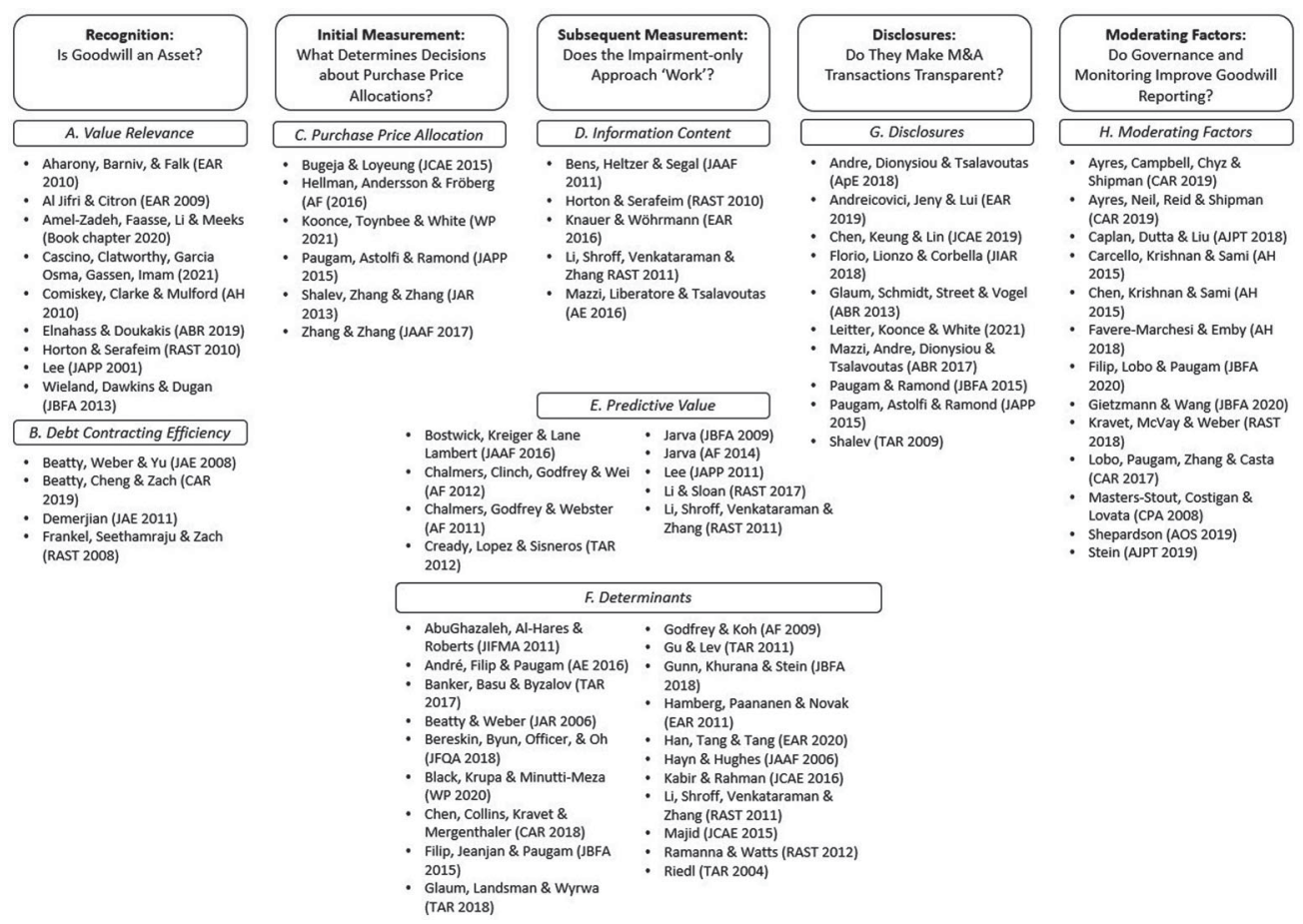

Figure 1. Empirical goodwill research

Taking the validity problems into account, our main findings are as follows. First, regarding recognition, goodwill from acquisitions is positively related to stock prices, i.e., value relevant, as well as predictive of future cash flows, suggesting that goodwill book values embody future economic benefits - both before and after the introduction of the IOA. Second, regarding the initial measurement of goodwill, the empirical evidence indicates that purchase price allocation decisions are associated with proxies for managerial incentives, suggesting that managers use the flexibility inherent in goodwill accounting opportunistically. Third, studies indicate that subsequent goodwill measurement decisions are determined not only by changes in the economic value of goodwill, but also by incentives. Fourth, studies document that related disclosures are often inadequate, and that noncompliance with disclosure requirements is again related to incentives. Fifth, goodwill impairment decisions and disclosure quality are associated with the intensity of monitoring and enforcement.

Thus, in sum, the literature indicates that goodwill accounting practices across the board appear to be shaped by incentives. However, it is not clear how much of a problem this is. Statistical associations between proxies for incentives and reporting outcomes do not necessarily imply that financial reporting is dominated by incentives. Goodwill amounts seem to correlate in theoretically expected ways with equity prices and financial performance, and goodwill-related disclosures appear to be informative to analysts, indicating some degree of decision usefulness. Furthermore, accounting standards purposely give managers discretion, and this necessarily opens up some room for earnings management. Unfortunately, empirical research does not allow us to conclude whether current goodwill accounting rules provide for an 'optimal' degree of discretion.

Given these findings, we propose two promising avenues for future research. First, we point out research questions that could be addressed using the currently dominating 
quantitative-archival methods. For example, future research could examine the riskiness of expected future benefits associated with goodwill from acquisitions, the factors that render goodwill amounts more or less useful for debt contracting, and the question whether investors agree with the assumption underlying the IOA that goodwill is an indefinite-lived asset. At a more general level, we argue that important findings in goodwill accounting should be challenged in reproduction studies, and we encourage standard setters to initiate quasi-experiments in the form of staggered introductions or random assignments of new accounting methods, to allow for valid causal inferences, and to render policymaking more accountable.

Our second set of proposals for future research is based on the observation that goodwill research is currently dominated by quantitative-archival studies based on (neo-institutional) economic theories. We suggest that researchers adopt a broader theoretical perspective, including investigating individual and collective psychological and sociological factors that shape decisions about goodwill accounting. Researchers should also deploy the full range of research methods. In particular, we believe that experiments and other forms of non-archival studies could deepen our understanding of goodwill accounting. The latter includs surveys and smallsample case studies that closely observe the actual behavior of, and the interaction between, decision-makers within firms.

Section 2 provides the institutional background on goodwill accounting and derives five guiding questions that structure our paper. Section 3 describes how we selected the studies in this review. For each of our five questions, Section 4 summarizes and discusses extant research, focusing on key findings of interest to future researchers and standard setters. Section 5 discusses validity problems in extant studies that may impede their usefulness in the policy debate, suggests possible approaches to addressing these problems, and summarizes what we can safely conclude from extant research. We then point out opportunities for future research. Section 6 concludes.

\section{Institutional Background}

\subsection{Historical Perspective}

Goodwill reflects the present value of expected future benefits from intangible assets that cannot be individually identified and are therefore not recognized separately. The consensus has been that internally generated goodwill should not be recognized because it is hard to identify and measure (Bloom, 2009). In contrast, goodwill from business combinations, which arises when the consideration paid by the acquirer exceeds the fair values of the target's identifiable net assets, has been controversial for many years. ${ }^{4}$

Until the early 2000s, US GAAP and IAS offered an implicit choice between two methods of accounting for business combinations. If a transaction qualified as a 'merger of equals', the pooling-of-interests method could be used, i.e., the assets and liabilities of the combining entities were carried forward in the consolidated financial statements at their book values, and any difference between the consideration paid and the target's book value of equity was adjusted against consolidated equity. The target's net assets were not revalued, no goodwill arose, and subsequent earnings were thus unaffected. All other transactions were accounted for under the purchase (acquisition) method, ${ }^{5}$ in which the acquirer recognizes the target's assets and liabilities

\footnotetext{
${ }^{4}$ See Ding et al.'s (2008) discussion of the history of goodwill accounting for four major countries (the UK, the US, France, and Germany), starting from the late nineteenth century.

${ }^{5}$ Traditionally and until the early 2000s, the FASB and the IASB used the term 'purchase method'; both standard setters later adopted the term 'acquisition method'.
} 
at their acquisition-date fair values, and any excess of the consideration paid over the fair value of net assets acquired is recognized as goodwill. The acquisition method typically dampened subsequent consolidated earnings and return ratios. First, goodwill itself was amortized, over a maximum of 20 years under IAS 22 and 40 years under APB 17. Second, the fair-value step-ups of most acquired assets would also be expensed. Third, goodwill and fair-value step-ups inflated the denominators of return ratios.

The marked differences between the pooling and purchase methods created strong incentives for acquirers to purposely structure transactions to fulfill the pooling criteria by labeling acquisitions 'mergers of equals', even where, economically, they were takeovers. ${ }^{6}$ Motivated by the perceived abuse of pooling (e.g., Walter, 1999), and after contentious deliberations, the FASB in 2001 issued SFAS 141 (now Accounting Standards Classification [ASC] 805) and SFAS 142 (now ASC 305), to abolish pooling and mandate the acquisition method for all business combinations (FASB, 2001a, 2001b). According to critical observers, firms were compensated for the 'lost benefits' of pooling by goodwill being treated as an asset with an indefinite useful life that would no longer be amortized, but only tested for impairment (Ramanna, 2008), with no drag on future earnings as long as no impairment arises. The IASB, too, adopted this impairment-only approach (IOA) via IFRS 3 and a revised IAS 36 in 2004.

The IASB's shift coincided with mandatory IFRS adoption in the EU in 2005. Pre-IFRS domestic-GAAP requirements for business combinations had been diverse even within the EU. ${ }^{7}$ For example, in most EU countries firms could choose, under certain conditions, between the acquisition and pooling methods. If firms chose the former, in most EU countries they were required to recognize and amortize goodwill, but with a variety of maximum amortization periods. In some countries (e.g., Germany), firms also were allowed to set off goodwill against reserves, without affecting profit or loss, or expense goodwill immediately. In the UK, FRS 10 introduced in 1997 represents an early example of the goodwill IOA (Amel-Zadeh et al., 2016).

\subsection{Current Requirements}

The now-mandatory acquisition method requires that the acquirer recognizes, at fair value, the individually identifiable assets of the target, including internally generated intangibles not previously recognized in the target's balance sheet, as well as the target's liabilities. If this purchase price allocation (PPA), after consideration of deferred taxes ${ }^{8}$, results in a positive difference between the acquisition cost and the fair value of the acquired net assets, this difference is recognized as goodwill. If it results in a negative difference ('badwill'), the acquirer recognizes it as a gain in profit or loss.

For subsequent impairment testing, goodwill is allocated to cash-generating units (CGUs, or, under US GAAP, reporting units, RUs) expected to benefit from the synergies of the deal. The test involves comparing the sum of the carrying amounts of the units' assets, including goodwill, with the units' fair values (US GAAP) or recoverable amounts (IFRS). ${ }^{9}$ The recoverable amount

\footnotetext{
${ }^{6}$ For example, MacDonald (1997) reports that about $90 \%$ of all U.S. business combinations over $\$ 100 \mathrm{~m}$ between 1992 and 1997 were accounted for using the pooling method.

${ }^{7}$ FEE (2002) summarizes accounting rules for business combinations and goodwill across European countries. For an overview of accounting rules covering countries outside Europe, see Nobes (2002).

${ }^{8}$ For details regarding the recognition of deferred taxes in business combinations, see IAS 12, paras 66 to 68.

${ }^{9}$ The tests can be performed at any time during the year, but must be done at the same time every year (IAS 36, para 96). Additional tests must take place whenever there are indications that goodwill might be impaired (IAS 36, para 90). SFAS 142 initially also required annual goodwill impairment tests. However, in 2011 the FASB introduced an option for companies to qualitatively assess the likelihood that goodwill is impaired; if management concludes that this is 'less likely than not', it need not perform the actual impairment test; see FASB Accounting Standards Update No. 2011-08.
} 
is the higher of a unit's fair value less costs of disposal and its value in use (IAS 36, para. 6). ${ }^{10}$ If the carrying amount is larger, an impairment loss is recognized in profit or loss. This loss is allocated to goodwill before other assets in the unit are written down (IAS 36, para. 104). Goodwill impairment losses must not be reversed in subsequent periods (IAS 36, para. 124).

\subsection{Controversy and Reform Discussion}

The goodwill IOA has been controversial from the start. Proponents hold that it will yield more decision-useful information because discrete impairment losses reflect the value decline of an indefinite-lived asset more accurately than amortization over some arbitrary useful life. Opponents argue that the IOA provides for wide discretion that managers can use opportunistically, for example, to delay or avoid necessary impairments (e.g., Ramanna \& Watts, 2012; Watts, 2003). For instance, identifying and revaluing intangible assets during the PPA requires judgment, allowing managers to influence the amount allocated to goodwill. Goodwill allocation to units also involves judgment, which managers may use to favor units with high levels of preexisting internally generated goodwill that in future years will serve as 'headroom' against potential impairment. ${ }^{11}$ Finally, recoverable amount calculations can be based on subjective and unverifiable firm-specific forecasts that are difficult to audit. ${ }^{12}$ Reports about rising goodwill balances ${ }^{13}$, lower-than-expected impairments even in times of economic crisis ${ }^{14}$, and incomplete and perceived 'boilerplate' goodwill-related notes disclosures also contributed to the debate. ${ }^{15}$ At the same time, preparers of financial statements furthermore argue that goodwill impairment tests are complex and unduly costly (see IASB, 2020, para. 4.5).

In response to the ongoing criticism, both the IASB and the FASB have been reconsidering their standards for the accounting of business combinations and goodwill (FASB, 2019; IASB, 2020), and in December 2020 the FASB reached a tentative Board decision to reintroduce amortization. ${ }^{16}$ The IASB, on the hand, has tentatively decided not to reintroduce amortization, arguing it 'has no compelling evidence that amortizing goodwill would significantly improve the information provided to investors' (IASB, 2020, para IN35(c)). However, this decision was taken with a narrow majority, and the board therefore decided to issue a discussion paper and 'ask stakeholders whether they can provide further evidence to help the IASB find a more conclusive answer to this question'. ${ }^{17}$ Furthermore, the IASB intends to provide relief from annual testing if

\footnotetext{
${ }^{10}$ Initially, the impairment test procedure mandated by SFAS 142 involved two steps. If the carrying amount of an RU was smaller than its fair value, in a second step management had to quantify the impairment loss by comparing the carrying value of the goodwill with its implied fair value, the latter being the difference between the unit's fair value and its revalued net assets. To reduce the cost of the test, the FASB in 2017 issued Accounting Standards Update No. 2017-04, which eliminated the second step and thus, in this regard, aligned US GAAP and IFRS requirements.

11 'Headroom' here refers to the gap between a CGU's fair value and its carrying amount including the new goodwill. In its recent deliberations, the IASB considered incorporating a headroom estimate into the goodwill impairment test; see IASB (2020, para 3.31-3.54). The approach considered by the IASB would require comparing the recoverable amount of a goodwill-carrying CGU with the sum of the carrying amounts of the assets and liabilities and the headroom of the unit at the previous impairment testing date ('updated headroom', para 3.40). The Board preliminarily decided against this approach, because it is complex and would not completely prevent shielding goodwill from impairment (para 3.53).

${ }^{12}$ For a more detailed discussion, see, for example, EFRAG $(2017,2016)$; AASB (2019).

${ }^{13}$ See, for example, ASBJ and Hong Kong Institute of Certified Public Accountants (2020); Duff and Phelps (2019).

${ }^{14}$ See, for example, FREP (2010); Glaum and Wyrwa (2011); also see IASB (2020, para 3.60).

${ }^{15}$ See, for example, ESMA (2014); Financial Reporting Council (2008).

${ }^{16}$ FASB project update on 'Identifiable Intangible Assets and Subsequent Accounting for Goodwill' available on https://www.fasb.org/jsp/FASB/FASBContent_C/ProjectUpdateExpandPage $\backslash \&$ cid=1176171566054 $\backslash \&$ pf=true (last accessed 22/04/2021)

${ }^{17}$ IASB (2019, para 32); also see Scott (2019) as well as Accounting Standards Board of Japan (2015) and European Financial Reporting Advisory Group (2017).
} 
there is no indication of impairment. It also plans to introduce additional disclosure requirements about firms' acquisition objectives and the acquired units' subsequent achievement of them.

\subsection{Guiding Questions}

In sum, goodwill accounting continues to confront standard setters with conceptual as well as practical issues. The central questions that structure our review can be summarized as follows (see Figure 1). ${ }^{18}$

(1) Recognition: Is acquired goodwill an asset, or should an excess of the purchase price over the fair value of acquired net assets be treated as an expense?

(2) Initial measurement: Do purchase price allocation requirements yield goodwill amounts that reflect future economic benefits, or should they be amended to restrict management discretion?

(3) Subsequent measurement: Does the goodwill IOA provide decision-useful information, or should amortization be reintroduced?

(4) Presentation and disclosure: Does goodwill-related presentation and disclosure provide decision-useful information, or should different or additional information be mandated?

(5) Moderating factors: Would enhanced corporate governance or auditing and enforcement improve the decision usefulness of goodwill-related information?

\section{Selection of Studies and Method of Review}

We review studies that examine goodwill accounting under the impairment-only approach. Searching the Social Sciences Citation Index of Web of Science, we retrieve all studies that include 'goodwill' in the title, abstract, or keywords in the period between January 2000 and December 2020. We limit our search to papers published in leading academic journals, using the Web of Science journal rankings by impact factor and by citations as our primary quality filter. We cross-reference the Web of Science rankings with those of the 2018 Association of Business School Academic Journal Guide in the UK and the German JOURQUAL 3 published by the German Academic Association for Business Research and select the top 30 journals at the intersection of these four lists. After excluding specialist journals in management accounting and tax, and those that primarily publish literature reviews, we arrive at a list of 26 journals.

In addition to studies from these journals and time period, we also consider older papers, unpublished working papers, and selected studies from other accounting journals, as well as from journals in cognate disciplines that provide additional insights into our research questions. We consider only papers that apply an empirical research design, and thus exclude solely theoretical and conceptual contributions, editorials, book reviews, comments, and replies. Our final selection includes 79 empirical studies. Table 1 lists the academic journals and their respective numbers of studies included in this review. As space constraints prevent us from discussing all studies in detail, we do so only for selected studies that we believe pioneer and illustrate the research pertinent to our questions. However, we tabulate summaries of all papers, listing their research questions, sample sizes, research designs, and main results, in the Online Supplement.

We note that our review includes primarily positivist, quantitative studies using archival data. This focus reflects the availability of pertinent goodwill accounting studies and is not a statement about the relative merits of different research approaches. On the contrary, as we explain in more

\footnotetext{
${ }^{18}$ These questions largely reflect the questions asked in the current discussion papers of the FASB and the IASB; see FASB (2019) and IASB (2020); also, see EFRAG (2017), Australian Accounting Standards Board (2019), Boennen and Glaum (2015), d'Arcy and Tarca (2018), and Wen and Moehrle (2016).
} 
Table 1. Academic journals and number of goodwill studies included in this review

Journal title Number of articles

Journal of Business Finance \& Accounting (JBFA) 8

Review of Accounting Studies (RAST)

The Accounting Review (TAR)

Journal of Accounting Auditing and Finance (JAAF)

European Accounting Review (EAR)

Accounting and Finance (AF)

Contemporary Accounting Research (CAR)

Journal of Accounting and Public Policy (JAPP)

Journal of Contemporary Accounting \& Economics (JCAE)

Accounting and Business Research (ABR)

Accounting Horizons (AH)

Journal of Accounting \& Economics (JAE)

Accounting in Europe (AE)

Accounting Organizations and Society (AOS)

Auditing - A Journal of Practice \& Theory (AJPT)

Journal of Accounting Research (JAR)

Applied Economics

Abacus-A Journal of Accounting Finance and Business Studies (Abacus)

Critical Perspectives on Accounting (CPA)

Journal of Financial and Quantitative Analysis (JFQA)

Journal of International Accounting Research (JIAR)

Journal of International Financial Management \& Accounting (JIFMA)

Accounting Auditing \& Accountability Journal (AAAJ)

Behavioral Research in Accounting (BRA)

International Journal of Accounting (IJA)

Journal of Financial Reporting (JFR)

Management Science (MS)

Other: working papers \& book chapters (WP)

Total

detail in Section 5.3, we strongly believe that non-archival studies (which are currently rare) including studies that reflect a constructivist research tradition - have much to add to the goodwill debate, and we view the different research traditions as fruitfully complementing each other.

\section{Insights from Empirical Goodwill Research}

\subsection{Recognition: Is Goodwill an Asset?}

Standard setters and academics have long discussed whether the purchase price allocation residual 'goodwill' qualifies for recognition as an asset. Johnson and Petrone (1998) argued in an influential paper that the benefits associated with goodwill 'are more nebulous and may be less certain' (p. 297) than those associated with most other assets. Ultimately, it thus is an empirical question whether current goodwill accounting practice generates decision-useful information. In the following, we discuss research that examines the asset nature of goodwill from the viewpoints of equity and debt investors.

\subsubsection{Value relevance and predictive ability studies}

Empirical accounting researchers have operationalized decision-usefulness by testing whether accounting amounts are 'value relevant', i.e., systematically correlated with stock prices (for a discussion of the literature, see Barth et al., 2001). To the extent that market prices co-vary with accounting amounts, it is inferred that investors' decisions and firms' financial statements draw on a common underlying information set. The value relevance approach has been used to 
investigate whether stock prices behave as if investors perceive goodwill as an asset. Before the US GAAP goodwill IOA, McCarthy and Schneider (1995) and Jennings et al. (1996) showed that acquired goodwill is value relevant, suggesting that investors interpret it as an asset. For the UK, Al Jifri and Citron (2009) corroborates this finding for both recognized and disclosed goodwill. Furthermore, Henning et al. (2000) documents positive associations of stock prices with the going-concern and synergy components of acquired goodwill, but negative associations for the overpayment and overvaluation components.

Online Supplement Table 1, Panel A, summarizes the more recent value relevance studies. Aharony et al. (2010) finds an increase in the value relevance of (changes in) goodwill in EU firms after mandatory adoption of IFRS (and the IOA) in 2005, compared to the previous year under local GAAP. This increase in value relevance is smaller in countries where local GAAP and IFRS are similar (e.g., UK, Ireland) and larger in countries where they differ (e.g., Germany, Austria). Amel-Zadeh et al. (2020) similarly documents an increase in the value relevance of goodwill under IFRS, comparing UK main market firms, which adopted IFRS in 2005, with alternative market firms, which continued reporting under UK-GAAP until 2007. ${ }^{19}$

The IASB's Conceptual Framework (F4.4(a)) defines an asset as a resource 'from which future economic benefits are expected to flow to the entity'. If acquired goodwill fulfills this definition, goodwill carrying amounts should help predict future cash flows. Lee (2011) confirms that they do predict one- and two-year-ahead cash flow for US firms, and the study suggests that this predictive ability has increased under the IOA.

In a rare non-archival study, Cascino et al. (2021) presents experimental evidence showing that subjects assess goodwill similarly to non-goodwill intangible assets as well as property, plant and equipment (PP\&E) in terms of perceived relevance. In terms of representational faithfulness, goodwill and non-goodwill intangible assets are again assessed similarly, with PP\&E viewed more favorably.

\subsubsection{Debt contracting efficiency}

Another stream of research examines the debt contracting efficiency of goodwill-related accounting amounts, and how the introduction of the IOA affected it (Online Supplement Table 1, Panel B). Beatty et al. (2008) finds that $43 \%$ of syndicated loan agreements had net worth covenants that were adjusted to exclude purchased intangibles, including goodwill. However, no clear-cut relation between the exclusion of purchased intangibles and firms' agency costs of debt is found. Frankel et al. (2008) finds that the exclusion of intangible assets from net worth loan covenants is negatively associated with the magnitude of goodwill, implying 'that lenders believe goodwill is informative and provides an efficient means of limiting agency costs' (p. 89). However, the use of tangible net-worth covenants increased after the introduction of SFAS 142, suggesting that 'these standards have reduced the contracting usefulness of goodwill' (p. 117). More recently, Beatty et al. (2019) documents a trend to exclude nonrecurring items, including goodwill impairment, from loan covenant calculations. Like in Frankel et al. (2008), this exclusion of goodwill impairments 'increases sharply after the adoption of SFAS 142 in 2002' (p. $148)^{20}$

\footnotetext{
${ }^{19}$ Examining the special case of gains from bargain purchases (negative goodwill, or 'badwill'), Comiskey et al. (2010) and Elnahass and Doukakis (2019) find that investors generally do not consider gains from bargain purchases to be value relevant. Several papers also examine the value relevance of earnings that include goodwill adjustments. Horton and Serafeim (2010) finds that goodwill amortization adjustments to IFRS reported earnings in UK firms' IFRS reconciliations are value relevant. Similarly, Wieland et al. (2013) documents that 'core earnings' adjusted for goodwill impairments are more value relevant than GAAP earnings.

${ }^{20}$ In a related study, Demerjian (2011) documents that the use of balance sheet covenants in loan contracts of U.S. firms declined between 1996 and 2007, whereas there was no discernible reduction of income-statement covenants. Demerjian
} 
In sum, value relevance and predictive ability studies indicate that recognized goodwill amounts are positively related to stock prices and firms' future cash flows, and thus that these amounts reflect future economic benefits. The evidence from archival studies regarding the debt contracting usefulness of goodwill itself is somewhat mixed, whereas goodwill impairment losses seem to be considered of low debt-contracting value. The introduction of the IOA is associated with lower use of certain covenants, potentially signaling that financial statements are now less useful for debt contracting.

\subsection{Initial Measurement: What Determines Decisions about Purchase Price Allocation?}

The studies in this section are summarized in Online Supplement Table 1, Panel C. Zhang and Zhang (2017) finds that managers of US firms allocate high proportions of the consideration transferred to goodwill when the likelihood of future impairments is low, i.e., when the acquirer has a high market-to-book ratio and large amounts of 'less verifiable' assets (Ramanna, 2008). The study also finds this pattern for firms with older CEOs, who may be less concerned about their future careers and thus about possible future goodwill impairment. Shalev et al. (2013) further documents that the portion of purchase price allocated to goodwill increases, ceteris paribus, with the importance of bonuses in CEOs' pay packages. Consistent with the notion that relatively high goodwill amounts are possibly overstated and thus discounted by the stock market, Paugam et al. (2015) finds that the proportion of the purchase price allocated to goodwill is associated with negative abnormal returns. The study also reports that 'abnormal goodwill' 21 is negatively (positively) associated with future firm performance (the frequency and magnitude of goodwill impairments following the acquisition). ${ }^{22}$ Overall, studies that examine the initial measurement of goodwill find evidence consistent with managers' opportunistic use of discretion, suggesting that managerial reporting, contracting, and compensation incentives are associated with allocating larger portions of the purchase price to goodwill.

\subsection{Subsequent Measurement: Does the Impairment-only Approach 'Work'?}

In this section, we distinguish studies that analyze the usefulness of goodwill impairment writeoffs for decision-makers (Section 4.3.1); whether impairment helps predict changes in cash flows (Section 4.3.2); and to what extent goodwill impairment write-offs reflect deterioration of the economic value of goodwill versus managerial incentives (Section 4.3.3).

\subsubsection{The information content of goodwill impairment charges}

Using the event-study method, information content studies analyze whether accounting disclosures convey new information to markets (Kothari, 2019, p. 358: 'information arrival studies'), and to what extent capital markets efficiently process accounting information. Before the IOA,

\footnotetext{
(2011) attributes this finding to changes in U.S. GAAP, including the new goodwill accounting rules and the trend towards fair value measurement, which led to increases in 'unverifiable balance sheet adjustments'. Similarly, Ball et al. (2015) finds a general reduction in accounting-based debt covenants following the introduction of IFRS. The authors argue that the reduction is caused by the greater managerial discretion and the increased use of fair value accounting under IFRS, which have impaired the contractibility of financial statements.

${ }^{21}$ Building on Shalev (2009), Paugam et al. (2015) regress goodwill on proxies for 'the underlying economics of the acquisition and the expectations of market participants' (p. 371), interpreting the residuals as 'abnormal goodwill'.

${ }^{22}$ Similarly, Bugeja and Loyeung (2015) finds an increase in the purchase price portion allocated to goodwill to be related to contracting incentives. An experimental study, Hellman et al. (2016) shows that equity analysts are more likely to expect acquisitions to enhance value if more of the acquisition premium is allocated to goodwill and to decrease value when more is allocated to amortizable intangibles. One tentative interpretation is that analysts perceive a lower goodwill allocation as reflecting reduced future growth opportunities. Another is that analysts consider amortization value-relevant potentially because of its negative effects on post-acquisition earnings-per-share accretion.
} 
Hirschey and Richardson (2002) found that stock market reactions to goodwill impairments announced in quarterly or annual reports were moderated by whether the contemporaneous earnings information was positive or negative. ${ }^{23}$ The announcement window captured only a small part of the overall market reaction, suggesting that investors largely anticipated the losses.

We summarize more recent studies in Online Supplement Table 1, Panel D. Studying the information content of goodwill impairment under the IOA, Knauer and Wöhrmann (2016) finds that investors in civil law countries (low investor protection) react more negatively than investors in common law countries (high investor protection). ${ }^{24}$ Further, negative abnormal returns appear less pronounced when an external (verifiable) write-off reason is provided, and more pronounced when an internal (unverifiable) reason is provided. Finally, abnormal returns to goodwill impairments do not differ significantly between US GAAP and IFRS firms, indicating that legal protection, not the accounting standards, drive the information content of the impairments. Li et al. (2011) and Bens et al. (2011) compare market reactions to goodwill-impairment announcements before and after the introduction of SFAS 142. Both studies document negative abnormal returns, and neither finds a significant change in how the markets react to large goodwill impairments after the introduction of SFAS $142 .{ }^{25}$

Overall, the studies in this branch of goodwill research thus document that goodwill impairments are informative to investors and suggest that verifiability might act as a moderating factor - a possibility examined further in the studies summarized in Section 4.5 below.

\subsubsection{Predictive value of goodwill impairment charges}

The FASB asserts in the introduction to SFAS 142 (p. 7) that the standard would 'provide users with a better understanding of the expectations about and changes in [goodwill] over time, thereby improving their ability to assess future profitability and cash flows'. Several studies, summarized in Online Supplement Table 1, Panel E, examine whether the FASB's assertion holds empirically.

Lee (2011) finds that goodwill impairment charges under SFAS 142 are significantly associated with year-ahead cash flows, i.e., the higher the impairment charge in year $t$ the lower tend to be cash flows in years $t+1$ and $t+2$, whereas goodwill-related charges (mainly amortization expense) were not significantly related to future cash flows before SFAS $142 .{ }^{26}$ Jarva (2009) also finds that goodwill impairments of US firms are associated with lower operating cash flows in the next two years, and Chalmers et al. (2011) suggests that goodwill impairments are negatively associated with investment opportunities (while amortization is not). ${ }^{27}$

\footnotetext{
${ }^{23}$ A positive market reaction to a goodwill impairment announcement is plausible if a firm's economic situation has deteriorated for some time and investors interpret the impairment as a signal that management will now take action to bring about a turnaround. Generally, the share price effect is likely to depend on the timeliness of the write-offs, and how the impairment is 'framed' by management and interpreted by investors; see Hirschey and Richardson (2002).

${ }^{24}$ The authors explain this moderating effect of the legal system with the notion that investors interpret write-offs of firms in civil law countries as 'a "lower bound" of the true write-off', because the low level of investor protection in these countries means that managers enjoy a lot of discretion (Knauer \& Wöhrmann, 2016, p. 440).

${ }^{25}$ Mazzi et al. (2016), surveying the views of 48 Italian CFOs, documents that the survey participants generally perceive the impairment test to be informative, but also subject to discretion.

${ }^{26}$ While Cready et al. (2012) also finds that goodwill impairment charges of U.S. firms in year $t$ are associated with lower future cash flows in year $t+1$, this study finds that goodwill impairment charges are associated with higher future earnings in the subsequent four years.

${ }^{27} \mathrm{Li}$ et al. (2011) similarly finds a negative correlation between impairment losses and subsequent sales growth and growth in operating income. The study also shows that goodwill impairments are related to subsequent downward revisions in analysts' earnings forecasts, suggesting 'that goodwill impairment losses are viewed as credible even by sophisticated market participants' (p. 766). In contrast, Chalmers et al. (2012) and Jarva (2014) do not find a significant association between goodwill impairment and analyst forecast accuracy.
} 
To sum up, these studies indicate that concurrent goodwill impairment is generally associated with negative future firm performance and that impairment announcement thus have predictive value for investors and other users of financial statements.

\subsubsection{Determinants and predictors of goodwill impairment}

Online Supplement Table 1, Panel F, summarizes studies investigating the determinants of goodwill impairment decisions. In most of these studies, the dependent variable of the empirical model is either binary (i.e., impairment versus no impairment) or the continuous amount or percentage written off. Explanatory variables include proxies for changes in the economic value of goodwill as well as proxies for managerial incentives. ${ }^{28}$ Early studies find asset write-offs to be associated with negative stock-market or accounting performance, but also with proxies for managerial incentives (Elliott \& Shaw, 1988; Francis et al., 1996; Riedl, 2004; Zucca \& Campbell, 1992). Beatty and Weber (2006) focuses on the first-time adoption of SFAS 142, when firms had an incentive to report transitional goodwill impairment losses, which were presented as special items ('below the line'), whereas subsequent impairment losses would be recorded 'above the line' in income from continuing operations. The study finds that the likelihood of a goodwill write-off upon first-time adoption is linked to debt-contracting, equity-market, and managerial labor market motives. Sellhorn (2004) also examines the determinants of transitional SFAS 142 goodwill write-offs by US firms. His findings indicate that on average, write-off behavior predominantly reflects economic circumstances, although there is some evidence that in large, visible firms managerial incentives affect goodwill impairment.

Analyzing the determinants of goodwill impairment under SFAS 142, Ramanna and Watts (2012) does not find that the firms' write-off decisions are related to management's private information, proxied by share repurchases, insider trading, and positive diction in annual reports. Instead, the study finds evidence suggesting that decisions on goodwill impairment are associated with debt contracting proxies, CEO compensation, CEO tenure, and proxies for 'unverifiable discretion' under SFAS $142 .{ }^{29}$ In contrast, AbuGhazaleh et al. (2011) reports that a sample of UK firms' impairments are more likely associated with the revelation of inside information than with opportunistic behavior. Following Ramanna and Watts (2012), Filip et al. (2015) labels firms with goodwill as 'suspect' if they do not report an impairment even though their book-to-market ratio is greater than 1 in two consecutive years. The study finds that 'suspect' firms report higher levels of abnormal cash flows than a matched sample of non-impairing firms. The authors conclude that firms 'manage their cash flow upward' to justify delaying goodwill impairments (p. 550).

Glaum et al. (2018) investigates the determinants of goodwill impairment for IFRS firms. In line with previous research, the study finds for an international sample that firms are more likely to report impaired goodwill in periods of CEO changes ${ }^{30}$ and when they may have an incentive to smooth earnings. These findings hold across enforcement regimes as well as in the presence of institutional investors, which may act as external monitors. ${ }^{31}$

\footnotetext{
${ }^{28}$ Some related studies attempt to trace write-offs back in time to the acquisitions that gave rise to the goodwill; others focus specifically on the role of auditors and internal controls. We discuss these lines of research below.

${ }^{29}$ Building on Ramanna (2008), Ramanna and Watts (2012) measures 'unverifiable net assets' directly by the proportion of nonfinancial net assets, or indirectly by the mean leverage of the firm's industry. The authors contend that firms with larger proportions of unverifiable net assets have more flexibility to manipulate the impairment decision (e.g., Ramanna \& Watts, 2012, p. 761).

${ }^{30} \mathrm{An}$ association of CEO changes or CEO tenures with asset write-downs was also pointed out by Francis et al. (1996), Riedl (2004), Beatty and Weber (2006), and Ramanna and Watts (2012). Further evidence of this relation is provided by Masters-Stout et al. (2008) and, anecdotally, in a case study by Hilton and O'Brien (2009).

${ }^{31}$ Furthermore, Hamberg et al. (2011) documents that Swedish firms' decisions to report goodwill impairment upon transition to IFRS in 2004 was related to a proxy for management entrenchment.
} 
A study by Li and Sloan (2017) provides evidence that suggests that the managers of US firms tend to delay necessary goodwill write-offs, in particular after the introduction of the IOA. As a result, goodwill write-offs can be predicted using simple accounting and market indicators (high goodwill balances, low return on assets, book-to-market $>1$ ). The study also shows that financial markets do not fully incorporate the available information, i.e., the aforementioned early-warning signals for goodwill impairment appear to predict stock prices in post-SFAS 142 periods.

Hayn and Hughes (2006) and Gu and Lev (2011) follow US acquirers over time and examine whether characteristics of the M\&A transactions can predict subsequent goodwill write-downs. Hayn and Hughes (2006) finds that acquisition characteristics and, to a lesser degree, the performance of goodwill reporting units partially predict future goodwill impairments. Overall, however, the predictive power of the model is rather low compared to that of conceptually similar bankruptcy models. Building on Shleifer and Vishny (2003), Gu and Lev (2011) suggests that overvaluation of acquirers' stock might induce managers to engage in value-destroying stock-for-stock acquisitions that ultimately lead to goodwill impairments. The authors show that overpricing indicators are linked to the frequency and value of acquisitions, and that the degree of overpricing is associated with the likelihood of future goodwill impairments. ${ }^{32}$

Consistent with these findings, Li et al. (2011) shows that higher acquisition premiums are associated with higher likelihood of subsequent impairments. Impairments are more likely after stock-financed acquisitions by growth firms and less likely when acquirer and target are in the same industry. More recently, Chen et al. (2018) shows that goodwill impairments are less likely where targets' financial statements are more comparable with those of industry peers, and Bereskin et al. (2018) suggests that transactions by culturally similar firms are associated with higher synergies and a lower likelihood of future goodwill impairment.

We conclude that goodwill impairment decisions and amounts are not fully explained by the underlying economic fundamentals of the combined entity, but vary systematically with managerial incentives, potentially reflecting the discretion inherent in the impairment testing requirements. Further, impairments can to some degree be predicted by acquisition characteristics and other indicators. In Section 4.5, we discuss governance and monitoring as moderating factors in this context.

\subsection{Disclosures: Do They Make M\&A Transactions Transparent?}

Both US GAAP and IFRS mandate extensive disclosures to enable investors to assess 'the reliability of the estimates used by management to support the carrying amounts of goodwill' (IFRS 36.BC205). However, there are complaints that firms' actual disclosures often do not fulfill these objectives. ${ }^{33}$ Confirming these concerns, Shalev (2009), Glaum et al. (2013), and Florio et al. (2018) document that large firms in the US and Europe often fail to make mandated disclosures. Such noncompliance is associated with firm characteristics, managerial incentives, and strength of enforcement. We summarize this strand of the literature in Online Supplement

\footnotetext{
${ }^{32} \mathrm{Gu}$ and Lev (2011) also shows that acquisitions by overpriced firms and the related goodwill impairments are negatively associated with firms' subsequent stock market performance, thereby refuting arguments that acquisitions by overpriced firms are value maximizing, and that goodwill write-offs are only a 'mechanical' by-product of the reversal of the overpricing.

${ }^{33}$ For example, a 2008 report by the UK Financial Reporting Council concluded that more than half of the reviewed disclosures on goodwill and goodwill impairment of UK firms in their 2007 financial reports were 'uninformative' (Financial Reporting Council, 2008). The European Securities and Markets Authority (ESMA, 2013, p. 3) concluded that the disclosures related to goodwill impairment testing in the 2011 financial reports of large stock-listed firms from 23 European countries 'in many cases were of a boilerplate nature and not entity-specific'. Also see ESMA (2014).
} 
Table 1, Panel G. Other studies investigate whether mandated IFRS disclosures about M\&A transactions (IFRS 3) and goodwill impairment testing (IAS 36) matter to capital market participants. The evidence suggests that the quality of these disclosures is positively related to analyst forecast accuracy (André et al., 2018; Paugam \& Ramond, 2015) and negatively related to forecast dispersion (André et al., 2018). Consistent with the latter finding, Andreicovici et al. (2020) shows that the transparency of firms' goodwill impairment disclosure is related to lower disagreement - among analysts as well as between analysts and managers - about the amounts and timing of impairments. ${ }^{34}$ Paugam and Ramond (2015) further shows that "prospective entityspecific impairment-testing disclosures are negatively associated with cost of capital [and analyst forecast dispersion] whereas descriptive disclosures exhibit no association with cost of capital' (p. 583).

In general, the empirical evidence suggests that the quality of M\&A- and goodwill-related disclosures varies greatly in practice, and that managers' disclosure decisions reflect their reporting incentives. Even so, these disclosures do appear to matter to analysts and investors, in that higher-quality M\&A-related disclosures are associated with reduced uncertainty and lower costs of capital.

\subsection{Moderating Factors: Do Governance and Monitoring Improve Goodwill Reporting?}

Several studies, summarized in Online Supplement Table 1, Panel H, examine the role of governance mechanisms and monitoring by auditors and market participants in firms' goodwill-related reporting decisions. Whereas external monitoring seems to enhance the credibility of disclosed fair value information (Muller \& Riedl, 2002; Müller et al., 2015), the evidence on its role in initial goodwill measurement is mixed. Zhang and Zhang (2017) finds evidence that involving external appraisers reduce managerial discretion and opportunistic behavior in purchase price allocations, but does not eliminate it completely. In contrast, Shalev et al. (2013) does not find that boards adjust managerial compensation when there is evidence of an overallocation to goodwill.

Examining impairment decisions, Glaum et al. (2018) finds that, in countries with strong (weak) enforcement, goodwill impairment tends to be more (less) strongly associated with declines in economic goodwill value. But in countries with weak enforcement, firms with high institutional investment exhibit the same sensitivities of goodwill impairment to declines in the economic value of goodwill as firms in high-enforcement countries, suggesting that private monitoring by institutional investors can substitute for public enforcement. ${ }^{35}$

Several papers further examine the relation between goodwill impairment and the quality of internal controls, as well as the monitoring role of auditors, audit committees, and financial analysts. Caplan et al. (2018) finds that US acquirers are more likely to recognize impairments following acquisitions if they report material SOX 404 internal control weaknesses. Goodwill newly recorded in the year following the remediation of such weaknesses has a lower likelihood of future impairment, presumably because M\&A decisions have improved. ${ }^{36}$ Gietzmann and Wang (2020) further shows that firms write off larger goodwill amounts when independent

\footnotetext{
${ }^{34}$ In related work, Paugam and Ramond (2015) and Mazzi et al. (2017) document negative associations between compliance with goodwill-related disclosure requirements and firms' cost of equity capital.

${ }^{35}$ Similarly, Kabir and Rahman (2016) shows that Australian firms with stronger governance exhibit a stronger association of economic factors with impairment losses, a finding confirmed for UK firms by AbuGhazaleh et al. (2011).

${ }^{36}$ Kravet et al. (2018) specifically examines firms that make use of a clause in the Sarbanes-Oxley Act that allows exempting newly acquired businesses from SOX 404 assessments. The study finds that using this exemption is associated with a higher chance of subsequent goodwill impairment as well as other negative post-acquisition outcomes (e.g., lower ROA and higher likelihood of restatements).
} 
valuation experts are involved in the impairment testing, and that these write-offs are associated more strongly with economic determinants. Overall, the results in this literature suggests that private and public monitoring reduces managerial discretion in goodwill impairment decisions.

Several studies also examine the role of auditors. Findings in Carcello et al. (2020) suggest that non-audit fees paid to a firm's auditors are associated with a lower likelihood of goodwill impairment. Lobo et al. (2017) examines French firms subject to mandatory joint audits, finding that firms audited by combinations of Big 4 and non-Big 4 auditors are more likely to report goodwill impairments and, when they do, to recognize larger impairment losses, than firms audited by two Big 4 auditors. ${ }^{37}$ Stein (2019) finds a positive association between the degree of industry specialization of auditors and the likelihood and volume of goodwill impairments. ${ }^{38}$ Overall, the evidence thus seems to suggest that auditor independence and auditor specialization are positively associated with the incidence and the size of goodwill impairments. ${ }^{39}$

Finally, Ayres, et al. (2019) examines the role of analysts, finding that the likelihood of goodwill impairment is more strongly related to expected impairment when analyst coverage is higher. Firms are also more likely to report goodwill impairment after analyst downgrades, and firms that fail to record expected impairments are more likely to experience a subsequent decrease in analyst following. In contrast, the findings of Han et al. (2021) in the Chinese market suggests that pressure from equity analysts to meet or beat earnings targets is negatively associated with goodwill impairments.

The research in this field has developed dynamically in recent years, and studies address different and sometimes quite specific aspects of goodwill accounting decision-making. The findings of the studies consistently indicate that in the presence of internal (control systems, boards) and external monitors (valuation experts, auditors, enforcement agencies, analysts, institutional investors) the likelihood and size of goodwill impairment tend to be higher and reported impairments more strongly related to expected impairments. Thus, the studies implicitly also suggest that managerial goodwill impairment decision-making is not entirely 'unverifiable' or 'unauditable'. Instead, strict internal and external monitoring appears to be effective in limiting managers' goodwill reporting discretion.

\section{Discussion}

This part of our paper proceeds in three steps. First, we discuss validity concerns in the empirical goodwill literature and explain how they limit interpretations of its findings (Section 5.1). We identify concerns that are specific to and common in goodwill accounting research, provide examples, and point out potential remedies where possible. Second, taking these limitations into account, Section 5.2 draws out what the studies reviewed in this paper allow us to safely conclude about the five guiding questions presented in Section 2.4. Finally, in Section 5.3 we outline pathways for future inquiry in empirical goodwill research, focusing on areas with potential for further quantitative-archival research, as well as perspectives for new research that uses other, currently less common methods.

\footnotetext{
${ }^{37}$ The study also finds that firms audited jointly by Big 4 and non-Big 4 auditors provide more transparent impairmentrelated disclosures than firms with only Big 4 auditors. The authors suggest two possible explanations. First, the clear difference between a Big 4 and a non-Big 4 auditor might make it easier to coordinate the joint audit. Second, in the presence of a non-Big 4 auditor, the Big 4 auditor has a stronger incentive to provide a high-quality audit.

${ }^{38}$ In line with Stein (2019), Shepardson (2019) finds that U.S. firms were more likely to write off goodwill if members of their audit committees had gained task-specific experience in other firms.

${ }^{39}$ A further study by Ayres et al. (2019a) documents that unexplained goodwill impairment decisions are positively related to the frequency of subsequent auditor dismissals.
} 


\subsection{Validity Problems in Empirical Goodwill Research}

Low validity in description, explanation, and prediction limits the value of empirical insights for scientific and policy debates. ${ }^{40}$ Drawing from the predictive validity model (Libby, 1981; Runkel \& McGrath, 1972), this subsection highlights specific challenges in the construct validity, internal validity and external validity of empirical goodwill research. These problems do not necessarily reflect researchers' shortcomings but are at least partly inherent in the subject matter. They should be borne in mind particularly when assessing research findings for their policy implications.

\subsubsection{Construct validity}

Construct validity requires that empirical researchers use dependent and independent variables in their empirical models each of which measures the respective conceptual variable, 'and that variable alone' (Libby et al., 2002, p. 796). Where concepts can be directly observed, research can use empirical measures to capture them; where they are unobservable, researchers need to rely on empirical proxies.

Research analyzing the determinants of goodwill-related reporting decisions requires variables that capture goodwill's underlying economics versus management's incentives. Most studies of impairment antecedents (see in Section 4.3.3) attempt to capture the impact of economic factors on goodwill impairment decisions by including variables such as market-to-book ratios, long-window stock returns, and accounting rates of return (e.g., Sellhorn, 2004). To increase test power, several studies restrict their samples to 'suspect' firms they consider likely to suffer economic impairment, using the same or similar indicators. ${ }^{41}$ Relying on such proxies, however, requires caution. First, whereas goodwill impairment tests are conducted the level of CGUs (IFRS) or RUs (US GAAP), researchers use firm-level proxies. Second, the presence of 'headroom' in goodwill-bearing units may prevent goodwill impairment when negative accounting or market performance may suggest that it is economically warranted. Third, managers may appropriately conclude that impairment of goodwill is unnecessary although market values are depressed - for example, if they believe that investors overreact to bad news. Consequently, Roychowdhury and Martin (2013) cautions that a book-to-market ratio greater than one may not always reliably indicate the need for asset write-downs. Similarly, Chen et al. (2019) warn against mechanical reliance on market-to-book ratios $<1$, which might pressure firms into unwarranted goodwill impairments. ${ }^{42}$

Some studies that investigate purchase price allocation and disclosure decisions (summarized in Sections 4.2 and 4.4, respectively) operationalize 'abnormal goodwill', the portion of goodwill unexplained by economic factors, as the residuals from a regression of goodwill on proxies for the deal's economics (e.g., Paugam et al., 2015; Shalev, 2009; Shalev et al., 2013). To the

\footnotetext{
${ }^{40}$ As Power and Gendron (2015, p. 159) explain, validity is primarily a concern for positivist research, including positive qualitative research, while 'constructivist research relies on different ideas about quality, namely the trustworthiness associated with a continuous effortful process of aligning data and theory'.

${ }^{41}$ Proxies for high ex-ante probability of 'economic goodwill impairment' include the market-to-book-value gap being smaller than recorded goodwill (e.g., Beatty \& Weber, 2006), the equity book-to-market ratio being greater than 1 in two consecutive years (e.g., Carcello et al., 2020; Filip et al., 2015; Ramanna \& Watts, 2012), and the presence of low-performance indicators (Lobo et al., 2017).

${ }^{42}$ Another issue in this literature, albeit unrelated to construct validity, relates to potential model misspecification. Banker et al. (2017) points out that determinant models may be misspecified because they typically assume a symmetric relationship between economic performance and write downs, instead of the asymmetric (conditionally conservative) relationship that underlies impairment testing requirements. To illustrate, Banker et al. (2017) compares a traditional 'symmetric' asset-write-down model based on Riedl (2004) with a model that uses asymmetric performance benchmarks, showing that the latter has higher explanatory power and leads to different inferences.
} 
extent that such determinant models include proxies for economic factors underlying goodwill that rely on market-to-book ratios, these studies have problems similar to those discussed above. Construct validity concerns may also relate to managerial incentive proxies. For example, Shalev et al. (2013) uses CEO income to capture the role of managerial incentives in purchase price allocations. However, the study focuses only on cash bonuses. Future studies could also include other elements of compensation (e.g., stock option grants) potentially related to goodwill recognition. ${ }^{43}$

As we explain further in Section 5.3, experimental designs might prove useful in disentangling empirical proxies for economic determinants and managerial incentives for goodwill-related reporting decisions, which are typically confounded in archival settings. Experiments allow the researcher to more directly infer the mechanisms driving goodwill accounting decisions by manipulating the variables of interest based on theories in economics and psychology. Archival researchers could also attempt to obtain finer data from 'special' cases in which the acquired companies continue to operate as separate entities, their financial information is disclosed separately, or they even continue to stay listed on stock exchanges. ${ }^{44}$ Furthermore, proprietary data shared by (groups of) firms could allow for more precise estimates of economic impairment. However, firms' willingness to share such data is unclear, because it would potentially expose goodwill-related earnings management.

Construct validity problems also occur in studies that attempt to measure the quality of goodwill disclosures using manual content analysis to construct quality and compliance indices (e.g., Andreicovici et al., 2020; Chen et al., 2019; Mazzi et al., 2017). These scoring models rely on researchers' subjective assessments and interpretations of disclosures, including the materiality of items, which affects weighting. ${ }^{45}$ Advances in textual analysis and natural language processing might help construct more objective measures of disclosure quality and allow for large samples to directly compare the disclosures with the requirements in the standards, e.g., through comparisons of vector representations or word embedding matrices of both texts (Gentzkow et al., 2019; Loughran \& McDonald, 2016). This is not to suggest, however, that automated content analysis is free from subjectivity.

\subsubsection{Internal validity}

Internally valid causal inference requires ruling out alternative explanations. The difficulties of causal inference in empirical-archival accounting research are well known (e.g., Gassen, 2014; Gow et al., 2016; Larcker \& Rusticus, 2010). Causal claims in empirical goodwill research relate to either the primary relation under study, e.g., the determinants of goodwill impairment, or a secondary, moderating effect on the relation under study, e.g., how the introduction of the impairment-only approach (IOA) affects the value relevance of goodwill. For the latter, several studies compare goodwill accounting outcomes (e.g., value relevance, predictive ability of goodwill, timeliness of goodwill impairment, proportions of the consideration transferred allocated to

\footnotetext{
${ }^{43}$ Shalev et al. (2013) also concedes that they cannot completely rule out the endogeneity of compensation structures. To address this issue, the study employs a 2SLS model that explains the bonus variable of interest in a first-stage regression and uses the predicted values in the second-stage regression.

${ }^{44}$ Examples for such special cases are Carillion's acquisition of Eaga in the UK, after which Carillion continued to disclose the main financial metrics of Eaga separately, and several acquisitions in China, after which the targets continued to trade on stock exchanges (Song \& Meeks, 2020).

${ }^{45}$ Construct validity can be an issue when a study introduces a novel measure to operationalize a theoretical concept. To illustrate, Andreicovici et al. (2020) reports tests of associations between a dependent variable - a disclosure transparency index composed of impairment-test-related footnote disclosures in annual reports - and a novel independent variable intended to capture analyst disagreement. To identify whether financial analysts anticipated the amount and timing of impairment, the study's measure of analyst disagreement relies on reports issued after the goodwill impairment announcements.
} 
goodwill) before and after the IOA to infer the effect of its introduction (e.g., Aharony et al., 2010; Lee, 2011; Li et al., 2011; Li \& Sloan, 2017; Zhang \& Zhang, 2017). However, before the IOA firms could use accounting policies that allowed them to avoid recognizing goodwill altogether, i.e., the pooling-of-interest method and, in Europe, setting off goodwill against reserves. Firms adopted these policies not at random but guided by managerial incentives. ${ }^{46}$ Furthermore, before-and-after comparisons may also be affected by important events (e.g., the dotcom bubble in the late 1990s and the financial crisis of 2008-2009) and by far-reaching changes in enforcement and oversight that took place in many countries in the early and mid-2000s (e.g., Christensen et al. 2013). Without controlling for firms' choices before the IOA and for potentially confounding contemporary events and changes, one cannot attribute before-and-after differences in outcomes to the IOA. We therefore recommend that authors and readers exercise appropriate caution in presenting and consuming, respectively, this evidence.

Internal validity problems also stem from endogenous relationships between the variables of interest or from reverse causality. For example, the fact that firms with abnormally high cash flows are less likely to report impaired goodwill may reflect managers' manipulations of real activities to avoid goodwill impairment (Filip et al., 2015; Filip et al. 2021) - or stronger economic performance. ${ }^{47}$ Without controls for all potential time-varying confounding factors (such as firms' underlying financial performance) driving both goodwill impairments and the independent variable of interest (cash flow), the absence of impairment does not establish managerial opportunism (see also Roychowdhury \& Martin, 2013). Although most studies include industry or firm fixed effects to absorb unobserved time-invariant confounders, this will not capture unobserved time-varying confounders such as changes in operating performance, changes in management teams, or changes in enforcement - all of which may affect impairments. Similarly, studies reporting associations between asset write-downs and CEO changes likely suffer from endogeneity, since impairments and CEO changes may simultaneously be caused by weak performance (see Beatty \& Weber, 2006; Francis et al., 1996; Glaum et al., 2018; Masters-Stout et al., 2008; Ramanna \& Watts, 2012; Riedl, 2004). Glaum et al. (2018) attempts to control for this possibility by differentiating between 'unforced' and 'forced' CEO changes (i.e., changes related to negative performance).

Econometric remedies for internal validity issues typically involve some estimate of the counterfactual, often in a difference-in-differences design. Such designs require comparable control groups, ideally randomly assigned, that are unaffected by the supposedly causal variable. Even though these ideal 'experimental settings' are rare outside the lab, archival researchers might be able to find quasi-experimental settings that introduce close-to-exogenous variation in the determinants of goodwill impairments under study or the staggered adoption of standards within a country. Amel-Zadeh et al. (2020), for example, attempts to control for unobserved heterogeneity across firms with goodwill balances by exploiting the staggered adoption of IFRS in the UK in a difference-in-difference setting comparing UK main market firms (treated with the IFRS

\footnotetext{
${ }^{46}$ For example, Zhang and Zhang (2017) acknowledges that, before SFAS 142, firms were able to opt for pooling treatment, but the study does not formally control for this choice. Li and Sloan (2017), as a robustness check, eliminate firms that applied the pooling method in pre-SFAS-142 years from their sample, but the study does not further address the fact that firms were allowed to opt for this accounting choice.

${ }^{47}$ Filip et al. $(2015,2021)$ examine 'suspect firms', i.e., firms with goodwill on their balance sheets that do not report goodwill impairment in year $t$, but have market-to-book ratios that are similar to other firms in their industries that did write off goodwill in $t$. Filip et al. (2015) concludes that the observed abnormally high cash flow in suspect firms reflect managers' manipulation of real activities to avoid goodwill impairment, rather than superior economic performance, which would justify the non-impairment of goodwill. However, as reported in Table 5 in Filip et al. (2015), in subsequent years suspect firms, on average, report increasing accounting returns and experience positive market returns, which appears to speak in favour of the superior economic performance explanation and not the real earnings management explanation.
} 
adoption) with propensity-score-matched control firms on the UK AIM market. Even in such quasi-experimental settings, however, as the treatment is usually not randomly assigned, internal validity hinges on how well the matching of control and treatment groups on observables captures unobserved heterogeneity across the groups.

Information content event studies are typically strong in internal validity, since they estimate abnormal stock market reactions within narrow windows around the events in question. ${ }^{48} \mathrm{How}-$ ever, these studies face potential confounding from other, contemporaneous information releases. For example, purchase price allocations are generally disclosed in annual reports, making any potential market reaction to the PPA difficult to isolate. Similarly, goodwill impairments are often accompanied by restructuring charges (Cready et al., 2012; Hirschey \& Richardson, 2002). Most studies control for concurrently announced unexpected earnings (e.g., Bens et al., 2011; Knauer \& Wöhrmann, 2016; Li et al., 2011), but investor reactions around the publication of financial statements might also be influenced by other concurrent disclosures (e.g., Francis et al., 2002).

\subsubsection{External validity}

Important to policymakers, external validity is the extent to which a study's insights are likely to generalize to other settings. Empirical goodwill studies are often performed on restricted samples. For example, many studies of impairment antecedents (summarized in Section 4.3.3) focus on firms with a high probability of 'economic goodwill impairment' - often fairly small samples that do not necessarily represent the average firm. ${ }^{49}$

Furthermore, goodwill-related reporting decisions and stakeholders' use of goodwill-related information likely reflect factors specific to the firm, stakeholder, and jurisdiction. Hence, singlecountry studies yield only limited insights into whether goodwill reporting requirements 'work' globally. Of the 79 studies reviewed here, 67 (85\%) are set in single jurisdictions (75\% of those in the US), whereas only $12(15 \%)$ sample from more than one country. Furthermore, these factors may evolve over time, creating a need for replication studies that reinvestigate the most important research questions in different jurisdictions and periods.

External validity problems also arise in studies investigating whether goodwill impairment predicts future firm performance (summarized in Section 4.3.2). Such studies do not claim to establish causality, but they do claim that a statistical association found between a set of lagged independent variables and an outcome variable of interest is sufficiently stable to allow reliable predictions of future values of the outcome from using contemporaneous values of the independent variables. However, Shmueli (2010, p. 304) cautions that a 'common practice... is to erroneously infer predictive power from explanatory power, which can lead to incorrect scientific and practical conclusions. ${ }^{50}$ Although the explanatory power of a model might be high due to overfitting parameters to the specific sample being tested, its predictive power, i.e., outof-sample explanatory power, might be low. A common remedy is to test predictive models on an 'unseen' sample, which was not used to estimate the parameters of the model. Bostwick et al. (2016) is among the few studies that performs out-of-sample tests to assess the predictive power of its models. Including goodwill impairment as a separate accrual component in the seminal model by Barth et al. (2001), Bostwick et al. (2016) finds that goodwill impairments incrementally predict negative future cash flows. In a similar vein, Hayn and Hughes (2006)

\footnotetext{
${ }^{48}$ In contrast, value relevance or predictive value studies typically measure the explanatory and outcome variables several months or years apart.

${ }^{49}$ For example, Beatty and Weber (2006) and Ramanna and Watts (2012) include 176 and 124 firms, respectively.

${ }^{50}$ This problem arises where studies rely exclusively on in-sample regressions in which the explanatory variables, $X$, well explain the outcome variable, $Y$, within a given sample. However, that same model may perform badly in predicting future values of $Y$ out of sample (e.g., in future periods or different countries) because of overfitting.
} 
estimates a hazard model of factors associated with future goodwill impairment, and then uses a holdout sample to establish that the model has some predictive power. Where existing studies report potentially interesting in-sample associations without addressing out-of-sample predictive power, opportunities for replication studies arise.

\subsection{What Can We Learn from Empirical Goodwill Research?}

Regarding recognition (i.e., whether goodwill is an asset), the evidence collectively indicates that goodwill amounts and impairment losses correlate in theoretically expected ways with proxies for the economic value of goodwill as well as indicators for firm value and financial performance. Both before and after the introduction of SFAS 142 and IFRS 3, goodwill is consistently shown to be value relevant and predictive of future cash flow.

Regarding the initial measurement of goodwill, the available evidence is consistent with the possibility that managers opportunistically use of the flexibility of goodwill accounting requirements - specifically, that purchase price allocation is associated with proxies for managerial incentives. Similarly, the prior research seems to suggest that subsequent goodwill measurements (i.e., impairments) are also associated with incentives. Nevertheless, goodwill impairment announcements seem to have information value, even though the market often appears to largely anticipate them. Although the evidence is not entirely consistent, the majority of studies indicate a negative relation with future operating performance. Furthermore, studies on the determinants of goodwill impairment consistently find impairment decisions to be associated with stock market returns or accounting performance.

Research also indicates that the quality of goodwill-related disclosures matters to financial analysts and investors. Discretion exists here, too, and managers' disclosure decisions seem to reflect their reporting incentives.

Finally, research on moderating factors suggests that goodwill impairment decisions and the quality of disclosures are related to the intensity of monitoring, oversight, and enforcement. To some extent, this supports the IASB's argument that problems in goodwill accounting may, at least partly, be an 'application issue that would best be addressed by other means, rather than by changing the standard' (Scott, 2019, p. 3). Yet Glaum et al. (2018) suggests that goodwill impairment decisions reflect managerial incentives even under strong enforcement, and many other studies documenting opportunistic managerial behavior are based on evidence from the US (e.g., Li et al., 2011; Ramanna \& Watts, 2012; Riedl, 2004), which is often characterized as having a strict enforcement regime. ${ }^{51}$

Empirical research on goodwill accounting thus leads to a nuanced overall conclusion. Whereas managerial incentives are pervasive, current reporting, on average, still appears to yield some degree of decision usefulness to analysts, investors, and other users. Several observations may explain this ambivalence. First, while the evidence suggests opportunistic use of goodwillrelated reporting discretion, financial statement users may 'see through' this manipulation at least partly. Second, evidence in earlier studies suggests that earnings management was already pervasive under the former US and international regimes that prescribed amortization and effectively gave firms a choice between the purchase and pooling-of-interest methods. For reasons discussed in Section 5.1.2, empirical studies have not clearly determined whether earnings management increased or decreased after the introduction of the IOA. Third, statistically significant associations between proxies for incentives and reporting outcomes in regression studies do not

\footnotetext{
${ }^{51}$ We hold the view that 'optimal' levels of monitoring and enforcement will ultimately emerge from political cost-benefit considerations, to which empirical studies can contribute partial analyses of specific costs or benefits.
} 
necessarily imply that reporting is dominated by incentives and the resulting accounting information thus useless. They 'only' mean that, given effect strength, variance, and sample size, these statistical associations are unlikely to be the product of chance. ${ }^{52}$ Finally, it is neither practically possible nor desirable to devise accounting rules that are completely prescriptive, leaving managers no room for judgment. Accounting standards purposely give managers discretion to allow them to adequately reflect a wide range of potentially complex transactions and events, and that discretion necessarily provides room for earnings management (e.g., Roychowdhury \& Martin, 2013). Unfortunately, empirical research does not allow us to conclude whether current U.S. GAAP or IFRS goodwill accounting rules provide for an optimal degree of discretion. ${ }^{53}$

\subsection{Pathways for Future Empirical Goodwill Research}

In this section, we provide suggestions for future empirical goodwill research. We first identify further questions that could be addressed with the currently dominating quantitative-archival methods (5.3.1). In Section 5.3.2, we then present perspectives for research using other methods. Here, we argue that new predictions and insights in goodwill research can come from more diverse theoretical foundations that put human decision-makers front and center, as well as a fuller range of (non-archival) research method(ologie)s used to undertake exploration and description in addition to (causal) explanation. ${ }^{54}$

\subsubsection{Research questions that remain unanswered}

Although the extant empirical goodwill research has made significant progress in advancing our knowledge of goodwill accounting, we nevertheless see promising avenues for further archival research in selected areas. In addition, we advocate replication studies, to challenge and verify the findings of important studies and to strengthen the available empirical evidence.

Recognition. Prior studies conclude that goodwill can be considered an asset, based on consistently finding that recognized goodwill is value relevant and has predictive value. However, there is no direct evidence so far regarding the uncertainty of the expected future benefits that acquired goodwill represents. Standard setters consider existence uncertainty (related to the inflow of benefits) and measurement uncertainty as criteria in determining whether items that meet the asset definition should be recognized on the balance sheet (see IFRS Conceptual Framework, paras. 5.14-5.23). Thus, the case for capitalizing goodwill as an asset could potentially be weakened if research showed that future economic benefits of goodwill tend to be highly uncertain. Such research could borrow from Kothari et al. (2002), which contributes to the debate on the capitalization of R\&D by comparing the associations of R\&D expenditures and capital expenditures with future earnings.

The evidence from studies on the debt contracting usefulness of goodwill is not entirely consistent. In particular, where goodwill-related amounts are excluded from covenants, it is unclear what motivates lenders and borrowers to do so. Whereas extant studies refer to the nonverifiability and low liquidation value of goodwill, only field evidence will ultimately get us closer to a full understanding of parties' decisions about the use of goodwill-related accounting amounts in covenants.

\footnotetext{
${ }^{52}$ The same caveat applies, mutatis mutandis, for observed statistical associations between proxies for (changes in) the economic value of goodwill and goodwill accounting outcomes.

${ }^{53}$ See Göx and Wagenhofer (2009) for an analytical model of optimal impairment rules; also see Ewert and Wagenhofer (2005) for a model that generally examines the consequences of tightening accounting standards.

${ }^{54}$ We thank the anonymous reviewers for making several very helpful suggestions included in this section.
} 
Initial and subsequent measurement. While the existing evidence suggests that goodwill amounts are value relevant, it is less clear whether investors agree with the assumption underlying the IOA that goodwill is an indefinite-lived asset. Evidence from an older study by Bugeja and Gallery (2006) as well as more recent findings from Amel-Zadeh et al. (2020) suggest that recently acquired goodwill is value relevant but loses its value relevance over time. ${ }^{55}$ Future research could more directly address this question by comparing the value relevance of reported goodwill balances under the IOA with 'as-if' amounts that simulate amortization under alternative useful life assumptions. To elicit market participants' views on the relative merits of the impairment and amortization models more directly, one could also survey analysts and investors about any adjustments they make to reported goodwill for assumed amortization, and their views on impairment. It would be especially fruitful if such field evidence were to indicate whether market participants' perceptions depend on any deal-specific context factors, such as the underlying synergies assumed, and how expectations about these factors are formed.

At a more general level, as mentioned above, the IASB is currently reconsidering its rules for business combinations accounting. More specifically, the Board has considered reintroducing amortization of goodwill as well as incorporating a headroom estimate into the goodwill impairment test. The headroom approach has never been applied in practice so that empirical research currently cannot assess its usefulness. Also, for reasons discussed in Section 5.1.2, empirical assessments of the IOA suffer from the confounding effects of alternative accounting methods (pooling or setting off goodwill against reserves) being used during the amortization regime. In this context, we strongly encourage standard setters and policymakers to consider closer cooperation with researchers, i.e., by field-testing new requirements such as modifications to the IOA or the (re-)introduction of goodwill amortization. If policymakers could be convinced to stagger the implementation of new requirements, or to assign new and potentially promising accounting methods only to a randomly determined 'treatment group' for a trial period of several years, while all other firms (i.e., the 'control group') would continue with existing standards, this would provide researchers with 'quasi-experimental' settings. ${ }^{56}$ Such settings approximate the 'gold standard' in research, the random experiment, and would thus allow empirical researchers to conduct internally valid causal effect studies. Initiatives of this kind would also help to align the objectives of researchers and standard setters. The research approaches would need to be jointly developed by academic researchers and standard setters, and the findings of such studies would render policymaking more accountable in the long run.

Disclosure. Existing studies find that M\&A- and goodwill related disclosures are decisionuseful to analysts and investors, but they generally do not provide evidence whether specific

\footnotetext{
${ }^{55}$ Also see Al Jifri and Citron (2009) in this context. This study, which we mentioned already above (see Section 4.1.1), explores a situation in the UK after the adoption of FRS 10, when goodwill from new acquisitions had to be capitalized while goodwill from prior acquisitions could either be reinstated and capitalized or remain eliminated against reserves and disclosed only in the notes. The study finds that both recognized and disclosed goodwill is positively associated with share prices, but the coefficient estimate of the recognized goodwill is larger than that of the disclosed goodwill. Several reasons may explain this particular finding. First, investors may attach more weight to recognized amounts than to amounts that are 'only' disclosed. Second, the disclosed goodwill tended to be older than the recognized goodwill. Third, the disclosed goodwill was not amortized and generally not tested for impairment.

${ }^{56}$ This suggestion may not be as naïve as it sounds. For example, the SEC has occasionally been known to conduct or facilitate such field experiments. Albuquerque et al. (2020) exploits the SEC's pilot program that increased the tick size for a number of randomly chosen stocks to study the price effects of liquidity shocks. Such policy experiments are also relatively common in economics (e.g., List, 2009). We do acknowledge that we currently see little indication that corporate reporting policymakers are inclined to follow suit.
} 
disclosures are useful or not. ${ }^{57}$ Future research could examine in more detail which specific goodwill-related disclosures are beneficial to financial statement users. However, empiricalarchival approaches to assessing the usefulness of individual disclosure items are challenging. First, mandatory disclosures may vary little, preventing the identification of associations or causal effects. Where they do (implying some degree of discretion), the association of disclosures with capital market outcomes of interest is likely confounded by common causes. Second, the 'bunched' nature of goodwill-related disclosures inhibits isolating the usefulness of any specific subset. Third, empirical-archival research cannot test the usefulness of goodwill-related disclosures that market participants may find useful (e.g., synergies) but that are not currently available. Here, survey and interview approaches could help, provided the researcher could successfully induce the subjects to (1) reveal their 'true' preferences and priorities with sufficient precision, and (2) consider the costs of these disclosures.

As mentioned above, we also expect improvements in disclosure studies to come from advances in textual analysis and natural language processing techniques. Automation of the analysis of disclosures and of the construction of disclosure indices will reduce the need to handcollect and hand-tag items, which is time consuming, potentially subjective and prone to error, allowing for higher-quality instruments and much-enlarged samples.

Replication and reproduction studies. Owing to a dearth of replication and reproduction studies, even key insights in empirical accounting research currently rest on shaky ground (e.g., Hail et al., 2020). ${ }^{58}$ To the extent that an empirical relation is considered important, efforts to enhance its external validity and to understand its underlying heterogeneity and moderators would be well invested. For example, most of the extant studies on goodwill accounting rely on US data. However, goodwill-related reporting is likely to be context- and time-specific. Thus, we suggest that scholars reproduce important and contentious goodwill accounting research, using data from different time periods and settings. Furthermore, empirical evidence for or against the efficacy of a reporting standard is more convincing if triangulated by studies using different methods, ${ }^{59}$ ideally including non-archival studies (we will elaborate on this line of argument below). Future reproduction studies could also take advantage of specific settings such as economic crises (e.g., the coronavirus pandemic) to 'stress-test' goodwill impairment requirements.

\subsubsection{A fuller range of theories and empirical methods}

At the risk of oversimplifying, the bulk of empirical goodwill research reviewed here draws on (neo-institutional) economic theories to derive its predictions. For example, studies analyzing the determinants of goodwill-related accounting choice mainly draw on positive accounting theory and capital-market incentives (e.g., Fields et al., 2001), and research on the informational value of goodwill-related accounting amounts largely assumes informationally efficient stock markets (e.g., Kothari, 2001). Yet, we know little about the individual and collective psychological and sociological factors that operate within firms' 'inner workings', or about how preparers' interactions with auditors and users shape their goodwill-related reporting. We also need to better understand how goodwill-related information is processed by analysts, investors, and other users.

\footnotetext{
${ }^{57}$ An exception is Paugam and Ramond (2015), which differentiates between descriptive and prospective disclosures regarding goodwill impairment testing. The study finds that only the latter are significantly negatively related to the firms' cost of capital and analyst forecast accuracy, whereas the former are not.

${ }^{58}$ Following Baker (2016), Hail et al. (2020) defines 'replication' as the process of exactly repeating a prior study, using the same dataset and method, and 'reproduction' as the process of repeating a prior study in a similar setting, with slight variations of method, sample or time period.

${ }^{59}$ An example of a mixed-method approach is that of Amel-Zadeh et al. (2019), which combines field evidence with textual analysis, trying to illuminate the process of narrative disclosures.
} 
Future research might therefore benefit from expanding its range of theories to those borrowed from behavioral disciplines. For example, recent experimental work has begun to shed light on the psychological drivers of goodwill-related reporting choices as well as users' processing of goodwill-related information (e.g., Favere-Marchesi \& Emby, 2018; Koonce et al., 2021; Leitter et al., 2021). ${ }^{60}$

Furthermore, it is hard to imagine that simply 'more' quantitative empirical-archival research will generate fundamentally new insights. Value relevance studies, event studies, and studies on the determinants of goodwill impairment all use large datasets and statistical methods to establish whether theoretical predictions about firms' accounting-related choices and the use of accounting information by financial statement users are, on average, supported by the data. However, these studies typically focus on narrow research questions and reduce complex realities to simple model relations (Power \& Gendron, 2015). We believe it would be helpful to complement this currently dominant form of research with other methods, such as surveys, clinical studies, or experiments. We therefore encourage more non-archival research engaging in exploration and description, which could advance both accounting theory and policymaking by shedding light on the motives, the actual behavior, and the interactions of the people involved in goodwill reporting.

For example, Huikku et al. (2017), one of the few qualitative studies, is based on semistructured interviews with financial accountants that illuminate the complexities of producing goodwill impairment amounts, including the dispersed components of the calculation, the process of acquiring pertinent evidence, and the assurance of results. Based on rich interview evidence of the goodwill impairment testing process, Huikku et al.'s (2017) 'study of financial accounting in action' (p. 69) concludes that '[n]o single person is responsible for the financial calculation' (p. 68), and 'the preparer is a network more than a single person' (p. 69) - exposing top management's actual involvement in these decisions (which archival studies often assume) as an open research question. ${ }^{61}$

Non-archival research might provide deeper insights into the information needs as well as information acquisition and processing strategies of financial reporting users. For example, as archival evidence on the debt contracting usefulness of goodwill is mixed, surveys and/or interviews could be a useful approach to studying in detail how bank managers perceive goodwill and how they treat it in loan contracts. Furthermore, proponents of the impairment-only approach sometimes argue that equity research analysts and other financial market participants ignore goodwill amortization because of its arbitrary nature (e.g., IASB, 2020, para. 3.88), and goodwill impairment amounts because of their non-cash nature (e.g., Gu \& Lev, 2011). A closer look into the 'black box' of analysts' valuation models and into the factors that determine the decisionmaking of portfolio managers could shed light on whether that is actually the case. Researchers could interview or survey analysts and institutional investors, or design lab experiments with

\footnotetext{
${ }^{60}$ For example, in a controlled experiment, Favere-Marchesi and Emby (2018) finds that audit managers are more likely to accept the CFO's decision that goodwill is not impaired, and are more confident about that decision, when the CFO is a former partner from their firm, particularly when from one of the Big4 firms. Koonce et al. (2021) documents that accounting professionals in the role of acquiring CFOs are more influenced by financial reporting incentives in their purchase price allocation when there is greater uncertainty in the fair value of intangibles; and Leitter et al. (2021) finds investors' perceptions of acquisitions are affected by whether intangible assets are separately identified or subsumed into goodwill.

${ }^{61}$ Whereas Huikku et al. (2017) follows a constructivist orientation and draws on actor-network theory, the study by Hilton and O'Brien (2009) is firmly rooted in the positivist tradition. This case study provides a detailed and critical account of the write-down decision making at Inco Ltd. following the acquisition of a large nickel mine in the 1990s.
} 
these important constituents to understand better how equity market participants perceive and treat goodwill. ${ }^{62}$

Field work is characterized by close interaction between researchers and preparers or users of financial statements. The rich descriptive information it generates is valuable in its own right (Power \& Gendron, 2015). Surveys or interview studies allow addressing complex, sensitive, or fine-grained issues that archival research cannot capture. For example, preparers apparently often claim that goodwill impairment tests are complex, burdensome, and costly. ${ }^{63}$ It would be interesting to investigate whether these claims are justified, and to understand where and how costs arise.

Importantly, field work could also improve archival quantitative research. Specifically, archival goodwill research has limitations that field data may help mitigate. First, the regression models used typically have large unexplained variation. Direct cooperation with preparers can enhance model specification by suggesting additional independent variables that enhance our understanding of, for example, the determinants of goodwill-related reporting decisions. Such variables could include more accurate controls for economic factors, but also new determinants that stem from observing managerial decision-making processes in their natural context, including the role of reputational concerns and personal traits, or moderating factors such as board oversight and auditors. Second, field data may expose interesting heterogeneity masked by average effects shown in archival tests, suggesting new cross-sectional predictions that can be taken to larger-scale archival data. Third, the insights gained in survey or case studies could enhance the construct validity of archival research by matching the relations modeled more closely to actual requirements and institutional details. For example, validity concerns about proxies for economic impairment based on firm-level data (see Section 5.1.1) could be addressed if researchers had access to subunit data, which would provide deeper insights into the replacement of acquired goodwill with internally generated goodwill ('headroom').

Finally, field evidence can help mitigate concerns about limitations to causal inference in archival studies, which often test reduced-form hypotheses, where the effects of confounding factors cannot always be fully ruled out. Using interviews or field observation to 'unpack' the chain that links the presumed causal variable to the outcome could render predicted causal effects more plausible, which could contribute to the credibility of causal inferences based on largesample archival evidence. For example, testing for the causal effect of CEO changes on goodwill impairment is complicated by confounding common causes of both, such as the firm's underlying economic situation. Documenting cases where newly appointed CEOs initiate steps to record material goodwill impairments and communicate them to capital markets as parts of comprehensive restructurings would enhance readers' confidence in the archival evidence. Further, field evidence might reveal additional mediators or moderators for the main effect of interest, adding nuance and richness to the original study.

\footnotetext{
${ }^{62}$ We are aware that non-archival studies tend to be costlier and riskier for researchers to conduct than archival studies. While collecting data from pre-structured databases is relatively easy, field studies and experiments require considerable time and effort to obtain access to a number of case firms, observe decision makers in action, and transcribe and analyze the resulting material. There is also typically no opportunity for a researcher to repeat an ill-conceived field study, questionnaire survey, or lab experiment, whereas archival researchers can always go back and procure more and different data. These risks may tend to discourage especially junior, untenured academics.

${ }^{63}$ See, for example, ACCA (2009). The FASB has already relieved companies of the obligation to perform annual goodwill impairment tests if there is no indication that impairments have occurred (FASB Accounting Standards Update No. 2011-08), and the IASB is currently suggesting the same simplification; see IASB (2020, para 4.1-4.6).
} 


\section{Conclusion}

The research reviewed here documents that goodwill reporting reflects the underlying economics of firms involved in business combinations, but is also shaped by managerial incentives and institutional context. Due to validity problems common to empirical-archival accounting research, this body of studies by itself does not yield unequivocal policy implications. For example, whether reporting requirements should be 'tightened' to limit managerial discretion ultimately remains a political decision.

In addition to pointing out several concrete research questions to be addressed by quantitativearchival researchers, we make suggestions that we believe could advance theory and evidenceinformed policymaking in goodwill accounting and corporate reporting in general. First, we suggest that reproducing important research studies in multiple contexts would strengthen our knowledge about issues that researchers and practitioners care about. Second, we encourage standard setters to enable quasi-experiments, by introducing new accounting methods in a staggered form or by assigning them to randomly chosen sets of 'treatment' companies, to allow for valid causal inferences and to render policymaking more accountable.

This review has emphasized positivist research methodology and causal inference. Although these foci reflect large parts of the literature we summarize (as well as our personal backgrounds) we do advocate a broader perspective and greater use of behavioral theories and non-archival methods. First, causal relations, although of eminent interest to policymakers and researchers alike, are only one element of the Roethlisberger (1977) knowledge enterprise diagram (Kaplan, 2019). Before 'going for causal inference', researchers should observe, systematically classify, and carefully describe the field of interest. Second, where causal statements are intended, there are many ways other than sophisticated econometrics and quasi-experimental settings to make a causal statement more credible, including convincing theory, systematic field evidence, and even anecdotal evidence. When using archival variables like accounting records and security prices, researchers do not observe human behavior directly and should therefore be cautious with inferences regarding actual decision making and underlying motives. Non-archival research, including surveys and small-sample case studies, is better suited to answer 'why' and 'how' research questions. Third, no single study should be expected to deliver the one causal 'silver bullet'. It may be more productive to think of causal statements as being made by a field, i.e., a wide range of diverse papers that bring different methods and data to bear - slowly and steadily building up evidence (including replicate evidence) that ends up suggesting a plausible causal effect. ${ }^{64}$ Diversity is important, as studies using similar research approaches are often subject to similar validity problems.

\section{Acknowledgements}

We thank Andreas Barckow, Tim Craig, Hervé Stolowy (the Editor), Ana Simpson, Ann Tarca, two anonymous reviewers, and participants at the 2nd EAA Financial Reporting Standards workshop for helpful comments and suggestions. Thorsten Sellhorn gratefully acknowledges funding by the Deutsche Forschungsgemeinschaft (DFG, German Research Foundation): Project-ID 403041268 - TRR 266 Accounting for Transparency.

\section{Disclosure statement}

No potential conflict of interest was reported by the author(s).

\footnotetext{
${ }^{64}$ For example, the research linking smoking to lung cancer built over decades, with no single causal study that settled the issue once and for all. The same seems to be happening with research on the effect of human-caused carbon emissions on world climate, with some people getting convinced later than others.
} 


\section{Funding}

This work was supported by Deutsche Forschungsgemeinschaft [grant number 403041268].

\section{Supplemental Data and Research Materials}

Supplemental data for this article can be accessed on the Taylor \& Francis website, https://doi.org/10.1080/09638180. 2021.1983854

ONLINE SUPPLEMENTAL MATERIALS: Online Supplement Table 1. Empirical Goodwill Literature.

\section{ORCID}

AMIR AMEL-ZADEH (D) http://orcid.org/0000-0002-0176-1093

MARTIN GLAUM (D) http://orcid.org/0000-0002-9300-1410

THORSTEN SELLHORN (D) http://orcid.org/0000-0003-2184-0968

\section{References}

AbuGhazaleh, N. M., Al-Hares, O. M., \& Roberts, C. (2011). Accounting discretion in goodwill impairments: UK evidence. Journal of International Financial Management \& Accounting, 22(3), 165-204. https://doi.org/10.1111/ j.1467-646X.2011.01049.x

ACCA. (2009). ACCA members survey: Complexity in financial reporting. Certified Accountants Educational Trust (London).

Accounting Standards Board of Japan. (2015, May). Research on amortization of goodwill (Discussion Paper).

Accounting Standards Board of Japan. (2017, July). Goodwill and impairment. Accounting Standards Advisory Forum. Accounting Standards Board of Japan and Hong Kong Institute of Certified Public Accountants. (2020, March). Goodwill: Improvements to subsequent accounting and an update of the quantitative study (Research Paper).

Aharony, J., Barniv, R., \& Falk, H. (2010). The impact of mandatory IFRS adoption on equity valuation of accounting numbers for security investors in the EU. European Accounting Review, 19(3), 535-578. https://doi.org/ $10.1080 / 09638180.2010 .506285$

Albuquerque, R., Song, S., \& Yao, C. (2020). The price effects of liquidity shocks: A study of the SEC's tick size experiment. Journal of Financial Economics, 138(3), 700-724. https://doi.org/10.1016/j.jineco.2020.07.002

Al Jifri, K., \& Citron, D. (2009). The value-relevance of financial statement recognition versus note disclosure: Evidence from goodwill accounting. European Accounting Review, 18(1), 123-140. https://doi.org/10.1080/096381808023 24351

Amel-Zadeh, A., Faasse, J., Li, K., \& Meeks, G. (2020). Stewardship and value-relevance in accounting for the depletion of purchased goodwill. In A. Amel-Zadeh \& G. Meeks (Eds.), Accounting for M\&A: Uses and abuses of accounting in monitoring and promoting merger. Routledge Studies in Accounting (pp. 79-112). Routledge.

Amel-Zadeh, A., Meeks, G., \& Meeks, J. G. (2016). Historical perspectives on accounting for M\&A. Accounting and Business Research, 46(5), 501-524. https://doi.org/10.1080/00014788.2016.1182703

Amel-Zadeh, A., Scherf, A., \& Soltes, E. (2019). Creating firm disclosures. Journal of Financial Reporting, 4(2), 1-31. https://doi.org/10.2308/jfir-52578

André, P., Dionysiou, D., \& Tsalavoutas, I. (2018). Mandated disclosures under IAS 36 impairment of assets and IAS 38 intangible assets: Value relevance and impact on analysts' forecasts. Applied Economics, 50(7), 707-725. https://doi.org/10.1080/00036846.2017.1340570

André, P., Filip, A., \& Paugam, L. (2016). Examining the patterns of goodwill impairments in Europe and the US. Accounting in Europe, 13(3), 329-352. https://doi.org/10.1080/17449480.2016.1260748

Andreicovici, I., Jeny, A., \& Lui, D. (2020). Disclosure transparency and disagreement among economic agents: The case of goodwill impairment. European Accounting Review, 29(1), 1-26. https://doi.org/10.1080/09638180.2019.167 7259

Australian Accounting Standards Board (AASB). (2019). Compiled Accounting Standard 3 - business combinations.

Ayres, D. R., Campbell, J. L., Chyz, J. A., \& Shipman, J. E. (2019b). Do financial analysts compel firms to make accounting decisions? Evidence from goodwill impairments. Review of Accounting Studies, 24(4), 1214-1251. https://doi.org/10.1007/s11142-019-09512-0

Ayres, D. R., Neal, T. L., Reid, L. C., \& Shipman, J. E. (2019a). Auditing goodwill in the post-amortization era: Challenges for auditors. Contemporary Accounting Research, 36(1), 82-107. https://doi.org/10.1111/1911-3846.12423

Baker, M. (2016). Is there a reproducibility crisis? Nature, 533(2016), 452-454. https://doi.org/10.1038/533452a 
Ball, R., Li, X., \& Shivakumar, L. (2015). Contractibility and transparency of financial statement information prepared under IFRS: Evidence from debt contracts around IFRS adoption. Journal of Accounting Research, 53(5), 915-963. https://doi.org/10.1111/1475-679X.12095

Banker, R. D., Basu, S., \& Byzalov, D. (2017). Implications of impairment decisions and assets' cash-flow horizons for conservatism research. The Accounting Review, 92(2), 41-67. https://doi.org/10.2308/accr-51524

Barth, M. E., Beaver, W. H., \& Landsman, W. R. (2001). The relevance of the value relevance literature for financial accounting standard setting: Another view. Journal of Accounting and Economics, 31(1-3), 77-104. https://doi.org/10.1016/S0165-4101(01)00019-2

Barth, M. E., Cram, D. P., \& Nelson, K. K. (2001). Accruals and the prediction of future cash flows. The Accounting Review, 76(1), 27-58. https://doi.org/10.2308/accr.2001.76.1.27

Beatty, A., Weber, J., \& Yu, J. J. (2008). Conservatism and debt. Journal of Accounting and Economics, 45(2-3), 154174.

Beatty, A., Cheng, L., \& Zach, T. (2019). Nonrecurring items in debt contracts. Contemporary Accounting Research, 36(1), 139-167. https://doi.org/10.1111/1911-3846.12426

Beatty, A., \& Weber, J. (2006). Accounting discretion in fair value estimates: An examination of SFAS 142 goodwill impairments. Journal of Accounting Research, 44(2), 257-288. https://doi.org/10.1111/j.1475-679X.2006.00 200.x

Bens, D. A., Heltzer, W., \& Segal, B. (2011). The information content of goodwill impairments and SFAS 142. Journal of Accounting, Auditing \& Finance, 26(3), 527-555. https://doi.org/10.1177/0148558X11401551

Bereskin, F., Byun, S. K., Officer, M. S., \& Oh, J. M. (2018). The effect of cultural similarity on mergers and acquisitions: Evidence from corporate social responsibility. Journal of Financial and Quantitative Analysis, 53(5), 1995-2039. https://doi.org/10.1017/S0022109018000716

Black, D. E., Krupa, J., \& Minutti-Meza, M. (2019). The optional qualitative assessment in impairment tests. https://ssrn.com/abstract=3322166

Bloom, M. (2009). Accounting for goodwill. Abacus, 45(3), 379-389. https://doi.org/10.1111/j.1467-6281.2009.00295.x

Boennen, S., \& Glaum, M. (2015). Goodwill accounting: A review of the literature. https://ssrn.com/abstract=2462516

Bostwick, E. D., Krieger, K., \& Lambert, S. L. (2016). Relevance of goodwill impairments to cash flow prediction and forecasting. Journal of Accounting, Auditing \& Finance, 31(3), 339-364. https://doi.org/10.1177/0148558X1559 6201

Bugeja, M., \& Gallery, N. (2006). Is older goodwill value relevant? Accounting \& Finance, 46(4), 519-535. https://doi.org/10.1111/j.1467-629X.2006.00181.x

Bugeja, M., \& Loyeung, A. (2015). What drives the allocation of the purchase price to goodwill? Journal of Contemporary Accounting \& Economics, 11(3), 245-261. https://doi.org/10.1016/j.jcae.2015.10.002

Caplan, D. H., Dutta, S. K., \& Liu, A. Z. (2018). Are material weaknesses in internal controls associated with poor M\&A decisions? Evidence from goodwill impairment. Auditing: A Journal of Practice \& Theory, 37(4), 49-74. https://doi.org/10.2308/ajpt-51740

Carcello, J. V., Neal, T. L., Reid, L. C., \& Shipman, J. E. (2020). Auditor independence and fair value accounting: An examination of nonaudit fees and goodwill impairments. Contemporary Accounting Research, 37(1), 189-217. https://doi.org/10.1111/1911-3846.12514

Cascino, S., Clatworthy, M. A., Garcia Osma, B., Gassen, J., \& Imam, S. (2021). The usefulness of financial accounting information: Evidence from the field. The Accounting Review, https://doi.org/10.2308/TAR-2019-1030.

Chalmers, K., Clinch, G., Godfrey, J. M., \& Wei, Z. (2012). Intangible assets, IFRS and analysts' earnings forecasts. Accounting \& Finance, 52(3), 691-721. https://doi.org/10.1111/j.1467-629X.2011.00424.X

Chalmers, K. G., Godfrey, J. M., \& Webster, J. C. (2011). Does a goodwill impairment regime better reflect the underlying economic attributes of goodwill? Accounting \& Finance, 51(3), 634-660. https://doi.org/10.1111/j.1467-629X.2010.00364.x

Chen, C. W., Collins, D. W., Kravet, T. D., \& Mergenthaler, R. D. (2018). Financial statement comparability and the efficiency of acquisition decisions. Contemporary Accounting Research, 35(1), 164-202. https://doi.org/10.1111/1911-3846.12380

Chen, W., Shroff, P. K., \& Zhang, I. (2019). Fair value accounting: Consequences of booking market-driven goodwill impairment (Working Paper). https://ssrn.com/abstract=2420528

Christensen, H. B., Hail, L., \& Leuz, C. (2013). Mandatory IFRS reporting and changes in enforcement. Journal of Accounting and Economics, 56(2-3), 147-177.

Comiskey, E. E., Clarke, J. E., \& Mulford, C. W. (2010). Is negative goodwill valued by investors? Accounting Horizons, 24(3), 333-353. https://doi.org/10.2308/acch.2010.24.3.333

Cready, W. M., Lopez, T. J., \& Sisneros, C. A. (2012). Negative special items and future earnings: Expense transfer or real improvements? The Accounting Review, 87(4), 1165-1195. https://doi.org/10.2308/accr-50152 
d'Arcy, A., \& Tarca, A. (2018). Reviewing IFRS goodwill accounting research: Implementation effects and cross-country differences. The International Journal of Accounting, 53(3), 203-226. https://doi.org/10.1016/j.intacc.2018.07.004

Demerjian, P. R. (2011). Accounting standards and debt covenants: Has the "balance sheet approach" led to a decline in the use of balance sheet covenants? Journal of Accounting and Economics, 52(2-3), 178-202. https://doi. org/10.1016/j.jacceco.2011.08.004

Ding, Y., Richard, J., \& Stolowy, H. (2008). Towards an understanding of the phases of goodwill accounting in four Western capitalist countries: From stakeholder model to shareholder model. Accounting, Organizations and Society, 33(7-8), 718-755. https://doi.org/10.1016/j.aos.2007.07.002

Duff \& Phelps. (2019, November). 2019 U.S. goodwill impairment study. https://www.duffandphelps.com/insights/ publications/goodwill-impairment/us-goodwill-impairment-report-2019.

Elliott, J. A., \& Shaw, W. H. (1988). Write-offs as accounting procedures to manage perceptions. Journal of Accounting Research, 26, 91-119. https://doi.org/10.2307/2491182

Elnahass, M., \& Doukakis, L. (2019). Market valuations of bargain purchase gains: Are these true gains under IFRS? Accounting and Business Research, 49(7), 753-784. https://doi.org/10.1080/00014788.2019.1609345

European Financial Reporting Advisory Group. (2016, September). What do we really know about goodwill and impairment? (Discussion Paper).

European Financial Reporting Advisory Group. (2017, June). Goodwill test—can it be improved? (Discussion Paper).

European Securities and Markets Authority (ESMA). (2013). European enforcers review of impairment of goodwill and other intangible assets in the IFRS financial statements. http://www.esma.europa.eu/system/files/2013-02.pdf

European Securities and Markets Authority (ESMA). (2014). Review on the application of accounting requirements for business combinations in IFRS financial statements. http://www.esma.europa.eu/system/files/2014-643_esma_ report_on_the_ifrs_3.pdf

Ewert, R., \& Wagenhofer, A. (2005). Economic effects of tightening accounting standards to restrict earnings management. The Accounting Review, 80(4), 1101-1124.

Favere-Marchesi, M., \& Emby, C. (2018). The alumni effect and professional skepticism: An experimental investigation. Accounting Horizons, 32(1), 53-63. https://doi.org/10.2308/acch-51920

Fédération des Experts Comptables Européens (FEE). (2002, March). FEE survey on business combinations.

Fields, T. D., Lys, T. Z., \& Vincent, L. (2001). Empirical research on accounting choice. Journal of Accounting and Economics, 31(1-3), 255-307. https://doi.org/10.1016/S0165-4101(01)00028-3

Filip, A., Jeanjean, T., \& Paugam, L. (2015). Using real activities to avoid goodwill impairment losses: Evidence and effect on future performance. Journal of Business Finance \& Accounting, 42(3-4), 515-554. https://doi.org/10.1111/jbfa.12107

Filip, A., Lobo, G. J., \& Paugam, L. (2021). Managerial discretion to delay the recognition of goodwill impairment: The role of enforcement. Journal of Business Finance \& Accounting, 48(1-2), 36-69. https://doi.org/10.1111/jbfa. 12501

Financial Accounting Standards Board (FASB). (2001a). Business combinations. Statement of Financial Accounting Standards 141.

Financial Accounting Standards Board (FASB). (2001b). Goodwill and other intangible assets. Statement of Financial Accounting Standards 142 .

Financial Accounting Standards Board (FASB). (2019, July). Identifiable intangible assets and subsequent accounting for goodwill (Discussion Paper).

Financial Reporting Council. (2008). Review of goodwill impairment disclosures.

Financial Reporting Enforcement Panel (FREP). (2010). Annual activity report. http://www.frep.info/docs/jahresberichte/ 2009/2009_tb_pruefstelle_eng.pdf

Florio, C., Lionzo, A., \& Corbella, S. (2018). Beyond firm-level determinants: The effect of M\&A features on the extent of M\&A disclosure. Journal of International Accounting Research, 17(3), 87-113. https://doi.org/10.2308/jiar-52226

Flyvbjerg, B. (2006). Five misunderstandings about case-study research. Qualitative Inquiry, 12(2), $219-245$. https://doi.org/10.1177/1077800405284363

Francis, J., Hanna, J. D., \& Vincent, L. (1996). Causes and effects of discretionary asset write-offs. Journal of Accounting Research, 34, 117-134. https://doi.org/10.2307/2491429

Francis, J., Schipper, K., \& Vincent, L. (2002). Expanded disclosures and the increased usefulness of earnings announcements. The Accounting Review, 77(3), 515-546. https://doi.org/10.2308/accr.2002.77.3.515

Frankel, R., Seethamraju, C., \& Zach, T. (2008). GAAP goodwill and debt contracting efficiency: Evidence from networth covenants. Review of Accounting Studies, 13(1), 87-118. https://doi.org/10.1007/s11142-007-9045-0

Gassen, J. (2014). Causal inference in empirical archival financial accounting research. Accounting, Organizations and Society, 39(7), 535-544. https://doi.org/10.1016/j.aos.2013.10.004 
Gentzkow, M., Kelly, B., \& Taddy, M. (2019). Text as data. Journal of Economic Literature, 57(3), 535-574. https://doi.org/10.1257/jel.20181020

Gietzmann, M., \& Wang, Y. (2020). Goodwill valuations certified by independent experts: Bigger and cleaner impairments? Journal of Business, Finance and Accounting, 47(1-2), 27-51. https://doi.org/10.1111/jbfa.12411

Glaum, M., Landsman, W. R., \& Wyrwa, S. (2018). Goodwill impairment: The effects of public enforcement and monitoring by institutional investors. The Accounting Review, 93(6), 149-180. https://doi.org/10.2308/accr52006

Glaum, M., Schmidt, P., Street, D. L., \& Vogel, S. (2013). Compliance with IFRS 3- and IAS 36-required disclosures across 17 European countries: Company- and country-level determinants. Accounting and Business Research, 43(3), 163-204. https://doi.org/10.1080/00014788.2012.711131

Glaum, M., \& Wyrwa, S. (2011). Making acquisitions transparent: goodwill accounting in times of crisis; an analysis of how European companies dealt with IFRS disclosures in the field of M\&A accounting (IFRS 3, IAS 36) in 2009 financial statements. Fachverl. Moderne Wirtschaft.

Göx, R. F., \& Wagenhofer, A. (2009). Optimal impairment rules. Journal of Accounting and Economics, 48(1), 2-16. https://doi.org/10.1016/j.jacceco.2009.04.004

Gow, I. D., Larcker, D. F., \& Reiss, P. C. (2016). Causal inference in accounting research. Journal of Accounting Research, 54(2), 477-523. https://doi.org/10.1111/1475-679X.12116

Gu, F., \& Lev, B. (2011). Overpriced shares, ill-advised acquisitions, and goodwill impairment. The Accounting Review, 86(6), 1995-2022. https://doi.org/10.2308/accr-10131

Gunn, J. L., Khurana, I. K., \& Stein, S. E. (2018). Determinants and consequences of timely asset impairments during the financial crisis. Journal of Business Finance \& Accounting, 45(1-2), 3-39. https://doi.org/10.1111/jbfa.12287

Hamberg, M., Paananen, M., \& Novak, J. (2011). The adoption of IFRS 3: The effects of managerial discretion and stock market reactions. European Accounting Review, 20(2), 263-288. https://doi.org/10.1080/09638181003687877

Han, H., Tang, J., \& Tang, Q. (2021). Goodwill impairment, security analysts, and information transparency. European Accounting Review, 30(4), 767-799. https://doi.org/10.1080/09638180.2020.1791725

Hayn, C., \& Hughes, P. J. (2006). Leading indicators of goodwill impairment. Journal of Accounting, Auditing \& Finance, 21(3), 223-265. https://doi.org/10.1177/0148558X0602100303

Hellman, N., Andersson, P., Fröberg, E., \& Cahan, S. (2016). The impact of IFRS goodwill reporting on financial analysts' equity valuation judgements: Some experimental evidence. Accounting \& Finance, 56(1), 113-157. https://doi.org/10.1111/acfi.12189

Henning, S. L., Lewis, B. L., \& Shaw, W. H. (2000). Valuation of the components of purchased goodwill. Journal of Accounting Research, 38(2), 375-386. https://doi.org/10.2307/2672938

Hilton, A. S., \& O'Brien, P. C. (2009). Inco Ltd.: Market value, fair value, and management discretion. Journal of Accounting Research, 47(1), 179-211. https://doi.org/10.1111/j.1475-679X.2008.00314.x

Hirschey, M., \& Richardson, V. J. (2002). Information content of accounting goodwill numbers. Journal of Accounting and Public Policy, 21(3), 173-191. https://doi.org/10.1016/S0278-4254(02)00048-0

Horton, J., \& Serafeim, G. (2010). Market reaction to and valuation of IFRS reconciliation adjustments: First evidence from the UK. Review of Accounting Studies, 15(4), 725-751. https://doi.org/10.1007/s11142-009-9108-5

Huikku, J., Mouritsen, J., \& Silvola, H. (2017). Relative reliability and the recognisable firm: Calculating goodwill impairment value. Accounting, Organizations and Society, 56, 68-83.

International Accounting Standards Board (IASB). (2019, July). Goodwill and impairment, summary of the IASB's research project (Staff Paper).

International Accounting Standards Board (IASB). (2020, March). Business combinations—disclosures, goodwill, and impairment (Discussion Paper).

Jarva, H. (2009). Do firms manage fair value estimates? An examination of SFAS 142 goodwill impairments. Journal of Business Finance \& Accounting, 36(9-10), 1059-1086. https://doi.org/10.1111/j.1468-5957.2009.02169.x

Jarva, H. (2014). Economic consequences of SFAS 142 goodwill write-offs. Accounting \& Finance, 54(1), 211-235.

Jennings, R., Robinson, J., Thompson, R. B., II, \& Duvall, L. (1996). The relation between accounting goodwill numbers and equity values. Journal of Business Finance \& Accounting, 23(4), 513-533. https://doi.org/10. 1111/j.1468-5957.1996.tb01024.x

Johnson, L. T., \& Petrone, K. R. (1998). Commentary: Is goodwill an asset? Accounting Horizons, 12(3). https://doi. org/10.2308/acch-10116

Kabir, H., \& Rahman, A. (2016). The role of corporate governance in accounting discretion under IFRS: Goodwill impairment in Australia. Journal of Contemporary Accounting \& Economics, 12(3), 290-308. https://doi.org/ 10.1016/j.jcae.2016.10.001

Kaplan, R. S. (2019). Reverse the curse of the top-5. Accounting Horizons, 33(2), 17-24. https://doi.org/10.2308/acch10663 
Knauer, T., \& Wöhrmann, A. (2016). Market reaction to goodwill impairments. European Accounting Review, 25(3), 421-449. https://doi.org/10.1080/09638180.2015.1042888

Koonce, L., Toynbee, S., \& White, B. J. (2021). The justifiability of financial reporting preferences in accounting for intangibles in business combinations. SSRN 3465719.

Kothari, S. P. (2001). Capital markets research in accounting. Journal of Accounting and Economics, 31(1-3), 105-231. https://doi.org/10.1016/S0165-4101(01)00030-1

Kothari, S. P. (2019). Accounting information in corporate governance: Implications for standard setting. The Accounting Review, 94(2), 357-361. https://doi.org/10.2308/accr-10651

Kothari, S. P., Laguerre, T. E., \& Leone, A. J. (2002). Capitalization versus expensing: Evidence on the uncertainty of future earnings from capital expenditures versus R\&D outlays. Review of Accounting Studies, 7(4), 355-382. https://doi.org/10.1023/A:1020764227390

Kravet, T. D., McVay, S. E., \& Weber, D. P. (2018). Costs and benefits of internal control audits: Evidence from M\&A transactions. Review of Accounting Studies, 23(4), 1389-1423. https://doi.org/10.1007/s11142-018-9468-9

Larcker, D. F., \& Rusticus, T. O. (2010). On the use of instrumental variables in accounting research. Journal of Accounting and Economics, 49(3), 186-205. https://doi.org/10.1016/j.jacceco.2009.11.004

Lee, C. (2011). The effect of SFAS 142 on the ability of goodwill to predict future cash flows. Journal of Accounting and Public Policy, 30(3), 236-255. https://doi.org/10.1016/j.jaccpubpol.2010.11.001

Leitter, Z., Koonce, L., \& White, B. J. (2021). The effect of identifying intangible assets in an acquisition on investors' judgements. Nanyang Business School (Research Paper No. 21-17).

Li, K. K., \& Sloan, R. G. (2017). Has goodwill accounting gone bad? Review of Accounting Studies, 22(2), $964-1003$. https://doi.org/10.1007/s11142-017-9401-7

Li, Z., Shroff, P. K., Venkataraman, R., \& Zhang, I. X. (2011). Causes and consequences of goodwill impairment losses. Review of Accounting Studies, 16(4), 745-778. https://doi.org/10.1007/s11142-011-9167-2

Libby, R. (1981). Accounting and human information processing: Theory and applications. Prentice-Hall.

Libby, R., Bloomfield, R., \& Nelson, M. W. (2002). Experimental research in financial accounting. Accounting, Organizations and Society, 27(8), 775-810. https://doi.org/10.1016/S0361-3682(01)00011-3

List, J. A. (2009). An introduction to field experiments in economics. Journal of Economic Behavior \& Organization, 70(3), 439-442. https://doi.org/10.1016/j.jebo.2008.10.013

Lobo, G. J., Paugam, L., Zhang, D., \& Casta, J. F. (2017). The effect of joint auditor pair composition on audit quality: Evidence from impairment tests. Contemporary Accounting Research, 34(1), 118-153. https://doi.org/10.1111/1911-3846.12244

Loughran, T., \& McDonald, B. (2016). Textual analysis in accounting and finance: A survey. Journal of Accounting Research, 54(4), 1187-1230. https://doi.org/10.1111/1475-679X.12123

MacDonald, E. (1997). Some high-tech firms' profits are being challenged by critics. Wall Street Journal, 7 May 1997, C1.

Masters-Stout, B., Costigan, M. L., \& Lovata, L. M. (2008). Goodwill impairments and chief executive officer tenure. Critical Perspectives on Accounting, 19(8), 1370-1383. https://doi.org/10.1016/j.cpa.2007.04.002

Mazzi, F., André, P., Dionysiou, D., \& Tsalavoutas, I. (2017). Compliance with goodwill-related mandatory disclosure requirements and the cost of equity capital. Accounting and Business Research, 47(3), $268-312$. https://doi.org/10.1080/00014788.2016.1254593

Mazzi, F., Liberatore, G., \& Tsalavoutas, I. (2016). Insights on CFOs' perceptions about impairment testing under IAS 36. Accounting in Europe, 13(3), 353-379. https://doi.org/10.1080/17449480.2016.1244341

McCarthy, M. G., \& Schneider, D. K. (1995). Market perception of goodwill: Some empirical evidence. Accounting and Business Research, 26(1), 69-81. https://doi.org/10.1080/00014788.1995.9729499

Muller, K. A., III, \& Riedl, E. J. (2002). External monitoring of property appraisal estimates and information asymmetry. Journal of Accounting Research, 40(3), 865-881. https://doi.org/10.1111/1475-679X.00074

Müller, M. A., Riedl, E. J., \& Sellhorn, T. (2015). Recognition versus disclosure of fair values. The Accounting Review, 90(6), 2411-2447. https://doi.org/10.2308/accr-51044

Nobes, C. (Ed.). (2002). GAAP 2001-A survey of national accounting rules benchmarked against international accounting standards. by Andersen, BDO, Deloitte Touche Tohamtsu, Ernst \& Young, Grant Thornton, KPMG and PricewaterhouseCoopers. J. Wiley \& Sons.

Paugam, L., Astolfi, P., \& Ramond, O. (2015). Accounting for business combinations: Do purchase price allocations matter? Journal of Accounting and Public Policy, 34(4), 362-391. https://doi.org/10.1016/j.jaccpubpol.2015.04.003

Paugam, L., \& Ramond, O. (2015). Effect of impairment-testing disclosures on the cost of equity capital. Journal of Business Finance \& Accounting, 42(5-6), 583-618. https://doi.org/10.1111/jbfa.12113

Power, M. K., \& Gendron, Y. (2015). Qualitative research in auditing: A methodological roadmap. Auditing: A Journal of Practice \& Theory, 34(2), 147-165. https://doi.org/10.2308/ajpt-10423 
Ramanna, K. (2008). The implications of unverifiable fair-value accounting: Evidence from the political economy of goodwill accounting. Journal of Accounting and Economics, 45(2-3), 253-281. https://doi.org/10.1016/j.jacceco. 2007.11.006

Ramanna, K., \& Watts, R. L. (2012). Evidence on the use of unverifiable estimates in required goodwill impairment. Review of Accounting Studies, 17(4), 749-780. https://doi.org/10.1007/s11142-012-9188-5

Riedl, E. J. (2004). An examination of long-lived asset impairments. The Accounting Review, 79(3), 823-852. https://doi.org/10.2308/accr.2004.79.3.823

Roethlisberger, F. J. (1977). The elusive phenomena. Harvard University Press.

Roychowdhury, S., \& Martin, X. (2013). Understanding discretion in conservatism: An alternative viewpoint. Journal of Accounting and Economics, 56(2-3), 134-146. https://doi.org/10.1016/j.jacceco.2013.11.001

Runkel, P., \& McGrath, J. (1972). Research on human behavior: A systematic guide to method. Holt, Rinehart and Winston.

Schatt, A., Doukakis, L., Bessieux-Ollier, C., \& Walliser, E. (2016). Do goodwill impairments by European firms provide useful information to investors? Accounting in Europe, 13(3), 307-327. https://doi.org/10.1080/17449480.2016.12 54348

Scott, T. (2019). Better information about business combinations-goodwill and impairment: Project update, 16. https://www.ifrs.org/-/media/project/goodwill-and-impairment/in-brief-goodwill-and-impairment-factsheet.pdf? la $=$ en

Sellhorn, T. (2004). Goodwill impairment: An empirical investigation of write-offs under SFAS 142. Peter Lang International Academic Publishers.

Shalev, R. (2009). The information content of business combination disclosure level. The Accounting Review, 84(1), 239-270. https://doi.org/10.2308/accr.2009.84.1.239

Shalev, R. O. N., Zhang, I. X., \& Zhang, Y. (2013). CEO compensation and fair value accounting: Evidence from purchase price allocation. Journal of Accounting Research, 51(4), 819-854. https://doi.org/10.1111/1475-679X.12015

Shepardson, M. L. (2019). Effects of individual task-specific experience in audit committee oversight of financial reporting outcomes. Accounting, Organizations and Society, 74, 56-74. https://doi.org/10.1016/j.aos.2018.07.002

Shleifer, A., \& Vishny, R. W. (2003). Stock market driven acquisitions. Journal of Financial Economics, 70(3), $295-311$. https://doi.org/10.1016/S0304-405X(03)00211-3

Shmueli, G. (2010). To explain or to predict? Statistical Science, 25(3), 289-310. https://doi.org/10.1214/10-STS330

Song, G., \& Meeks, G. (2020). The financial performance of acquired companies in the Chinese stock market. In A. Amel-Zadeh \& G. Meeks (Eds.), Accounting for M\&A: Uses and abuses of accounting in monitoring and promoting merger. Routledge Studies in Accounting (pp. 252-284). Routledge.

Stein, S. E. (2019). Auditor industry specialization and accounting estimates: Evidence from asset impairments. Auditing: A Journal of Practice and Theory, 38(2), 207-234. https://doi.org/10.2308/ajpt-52231

Walter, J. R. (1999). Pooling or purchase: A merger mystery. FRB Richmond Economic Quarterly, 85(1), 27-46.

Watts, R. (2003). Conservatism in accounting part I: Explanations and implications. Accounting Horizons, 17(3), 207221. https://doi.org/10.2308/acch.2003.17.3.207

Wen, H., \& Moehrle, S. R. (2016). Accounting for goodwill: An academic literature review and analysis to inform the debate. Research in Accounting Regulation, 28(1), 11-21. https://doi.org/10.1016/j.racreg.2016.03.002

Wieland, M. M., Dawkins, M. C., \& Dugan, M. T. (2013). The differential value relevance of S\&P's core earnings versus GAAP earnings: The role of stock option expense. Journal of Business Finance \& Accounting, 40(1-2), 55-81. https://doi.org/10.1111/jbfa.12013

Zhang, I. X., \& Zhang, Y. (2017). Accounting discretion and purchase price allocation after acquisitions. Journal of Accounting, Auditing \& Finance, 32(2), 241-270. https://doi.org/10.1177/0148558X15598693

Zucca, L. J., \& Campbell, D. R. (1992). A closer look at discretionary writedowns of impaired assets. Accounting Horizons, 6(3), 30 . 